Portland State University

PDXScholar

$1-1-2011$

\title{
Investigating Student Understanding of the Law of Conservation of Matter
}

Shirley Lynn Tremel

Portland State University

Follow this and additional works at: https://pdxscholar.library.pdx.edu/open_access_etds Let us know how access to this document benefits you.

\section{Recommended Citation}

Tremel, Shirley Lynn, "Investigating Student Understanding of the Law of Conservation of Matter" (2011). Dissertations and Theses. Paper 343.

https://doi.org/10.15760/etd.343

This Thesis is brought to you for free and open access. It has been accepted for inclusion in Dissertations and Theses by an authorized administrator of PDXScholar. Please contact us if we can make this document more accessible: pdxscholar@pdx.edu. 
Investigating Student Understanding of the Law of Conservation of Matter

$$
\text { by }
$$

Shirley Lynn Tremel

A thesis submitted in partial fulfillment of the requirements for the degree of

Master of Science in Teaching

in

General Science

\author{
Thesis Committee: \\ William Becker \\ Sybil Kelley \\ Cary Sneider
}

Portland State University

(C) 2011 


\begin{abstract}
The purpose of this study was to gather information about how students learn the foundational concept of conservation of matter during a non-chemistry unit on the rock cycle. The unit covered the rock cycle, rock types, and the law of conservation of matter and took place in a sixth grade classroom of 30 students. A mixed methods, quasi-experimental, pre-post, delayed post design was used to measure student understanding of the concept of conservation of matter as it relates to the rock cycle. Students made significant learning gains from pre-test to post-test and showed mastery in less complex subject areas, but struggled to learn the more complex concept of conservation of matter. More research is needed in order to gain a greater understanding of how students learn difficult foundational concepts such as conservation of matter, and how they are able to apply their understanding across disciplines in science. This study offers suggestions for future work including a series of questions to assess student misconceptions about matter, and how to use those questions to measure students' ability to transfer knowledge to different learning contexts. The recommended questions ask students to transfer knowledge from the conservation of matter as it applies to the rock cycle to chemistry concepts including conservation of matter, mass and volume.
\end{abstract}




\section{Table of Contents}

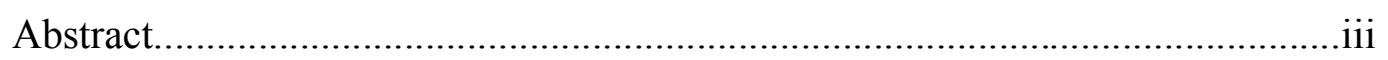

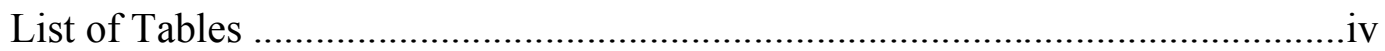

List of Figures......................................................................................

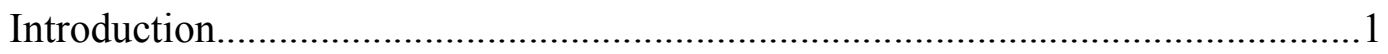

Literature Review................................................................................ 7

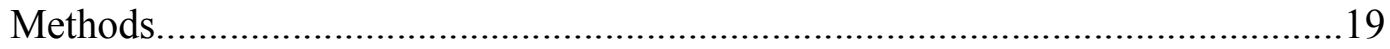

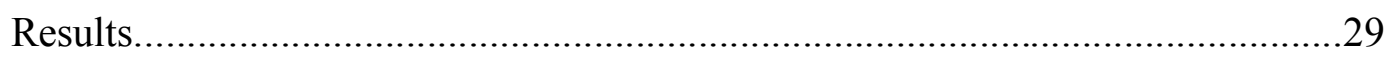

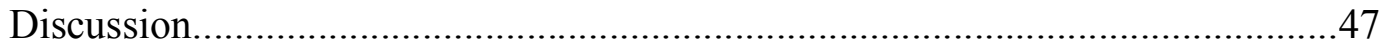

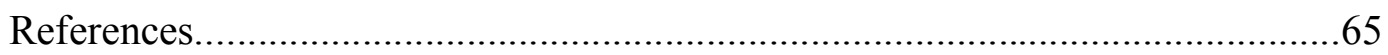

Appendices

A. Coding of Question 2 on Pre-Post and Question 1 on Delayed Post-Test........67

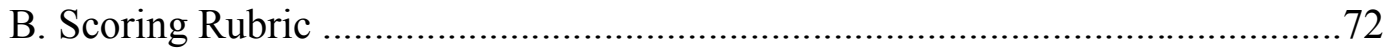

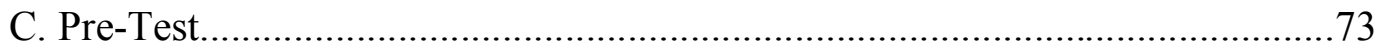

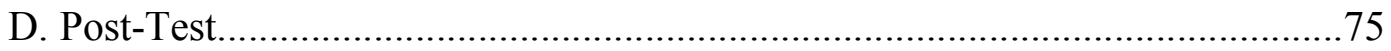

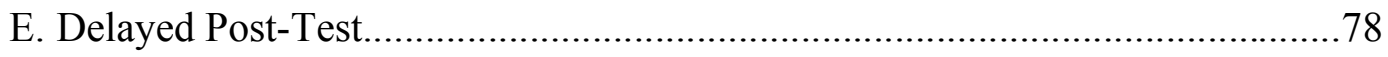

F. Human Subjects Approval............................................................... 79

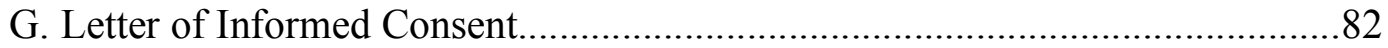




\section{List of Tables}

Table 1: Unit Goals and Objectives

Table 2: Rock cycle Unit Overview.

Table 3: Students who answered pre-test and post-test questions on rock types and conservation of matter correctly.

Table 4: Measures of statistical significance from pre-/post-test to delayed posttest on conservation of matter.

Table 5: Concept retention from post-test to delayed post-test.

Table 6: Students who had a decrease in scores from post- to delayed post-test.

Table 7: A closer look at students whose scores decreased from post-test to delayed post-test.

Table 8: Students who scored the same from post-test to delayed post-test.

Table 9: Students who scored higher on the delayed post-test than the post-test.

Table 10: Students who did not participate in delayed post-test.

Table 11: Case Study: Three students' progression of learning about conservation of matter and the rock cycle.

Table 12: Recommended questions for use when teaching a unit on the rock cycle and conservation of matter. 


\section{List of Figures}

Figure 1: Research design.

Figure 2: Comparison of correct answers on rock types and conservation pre-test to post-test for 30 students.

Figure 3: Change in average scores from pre-post-test to delayed post-test for 24 students.

Figure 4: Change in scores from post-test to delayed post-test for 24 students. 


\section{Introduction}

For students to understand the idea that matter cannot be created or destroyed is critical if they are to explain and understand the natural world (Pyke \& Ochsendorf, 2004). In fact, many scientists consider conservation laws related to matter and energy to be the most important laws in nature (Pyke \& Ochsendorf). Understanding conservation laws such as the law of conservation of matter, lays the foundation for students' understanding of the properties and changes of matter, a cornerstone in their ability to progress and learn more advanced scientific concepts in life science, Earth science, and physical science. National Science Education Standards (NSES) in physical science for fifth through eighth grade include properties and changes in matter to prepare ninth through $12^{\text {th }}$ grade students to learn about the structure of atoms, structure and property of matter, and chemical reactions (National Research Council [NRC], 1996).

Understanding foundational concepts such as the nature of matter can have a significant impact on students' ability to master other concepts in science (Liu, 2007). For example, properties and changes of matter becomes the basis for student understanding of atomic molecular theory, learning how to balance chemical equation, and stoichiometry. New research has shown a deficit in student understanding of chemical reactions, a concept that builds on the idea of

conservation of matter, particularly among sixth through $12^{\text {th }}$ grade students (Lempinen). Student understanding of chemical reactions is a key concept in 
advanced chemistry studies, but in biology as well, where many students learn about the chemistry of life (Lempinin, 2010).

Very recent research that points to a deficit in student understanding of chemical reactions is not surprising since many researchers have come to the conclusion that conservation of matter is a difficult concept to learn (Agung \& Schwartz, 2007; Gomez, Pozo, \& Sanz, 1995; Gulko, Doyle, Serbin, \& White, 2001; Piaget \& Inhelder, 1974; Stavy, 1990). Students learn conservation of matter gradually. Furthermore, Stavy (1990) reported students are more successful learning conservation of matter when it is connected to familiar concepts in different contexts while building on students' prior knowledge and experience. Recommendations for connecting to students' prior knowledge, and offering students multiple contexts in which to learn are not only best teaching practices, they are essential for students to be successful learning and applying difficult concepts such as conservation of matter.

Student understanding of conservation of matter has been studied internationally in an effort to find out how students respond to paper and pencil tests, interview questions, and conservation tasks. In studying how students respond to questions about conservation of matter, researchers have uncovered common student misconceptions about matter. International studies confirm the pervasiveness of misconceptions, adding to the research about conservation of matter as a difficult concept for students to learn (Ozmen \& Ayas, 2003).

Students show a variety of different skills and abilities when it comes to 
their ability to conserve matter. Piaget and Inhelder (1974) showed how difficult and complex conservation of matter concepts are for young students to understand. Piaget and Inhelder also determined student understanding of conservation of matter is heavily dependent on where they are in the four stages of cognitive development. Piaget and Inhelder's work led to a large body of research conducted in the area of how students learn about conservation of matter. However, the current body of research has been confined to how students learn this key concept in chemistry even though the literature suggests that students would benefit from learning the concept of conservation of matter across disciplines in science and in different learning contexts (Stavy, 1990; Stavy, 1991).

Research in the area of how students learn about matter has established a need for developmentally appropriate teaching methods, learning progressions, and instructional recommendations across the grades. More work needs to be done to show how students learn this concept in non-chemistry instructional units. As students gain opportunities to learn key concepts such as conservation of matter across science disciplines, they may become expert learners, and without a clearer understanding of how students learn this concept educators may be missing opportunities to help students be more successful.

To help fill this gap in the literature and to gain insight into the way students learn about conservation of matter, this study incorporated the concept of conservation in a two-week unit on the rock cycle. The aim is to better understand 
how young adolescents create a foundation of scientific knowledge composed of core concepts and big ideas across disciplines in science. By looking at the contributions of science education research on how students respond to conservation tasks and assessments, this study seeks to identify key factors that contribute to student success in learning about conservation of matter. In addition, this study draws from current research on learning progressions to make instructional recommendations toward helping students master a difficult concept.

As the researcher and student teacher in the classroom of this study, I taught a unit on the rock cycle to a group of sixth grade science students. The unit covered the three main rock types and how they are formed, the rock cycle, and the law of conservation of matter. Of these concepts, students had no trouble understanding concepts about the rock types and the rock cycle, but not surprisingly they struggled to learn the more difficult concept of law of conservation of matter, a core concept in science. My goal as the teacher was to help students connect a difficult concept to their prior knowledge and experiences with rocks and basic chemistry concepts such as changes in matter.

\section{Research Question}

\section{How do middle school students build an understanding of conservation of matter during a two-week unit on the rock cycle?}

Students need to be exposed to a variety of instructional methods and learning opportunities across science disciplines to develop mastery of difficult science concepts. As they build knowledge and understanding over time, they 
engage in more meaningful learning and become expert learners with the ability to transfer and apply their knowledge to different scenarios and in different learning contexts.

I hypothesized that connecting conservation of matter to the rock cycle, a concept familiar to students, would serve as a platform for them to learn the more complex and difficult to understand concept of conservation of matter. I also knew that most, if not all of my students, would have prior knowledge and experience with rocks to draw from and connect to their everyday lives. As a teacher who has had experience working with young adolescents, and a researcher familiar with the literature on learning progressions, misconceptions, and cognitive development, I predicted that sixth grade students would struggle with the concept of conservation of matter more than less complex concepts such as rock types and the rock cycle. Results of the pre-test reinforced my prediction about what concepts students would struggle with, so I designed lessons and activities aimed to help students understand the concept of conservation of matter while providing students with opportunities to build on their prior knowledge.

This study is a mixed methods, quasi-experimental pre-post, delayed-posttest design. The participants included 30 students from a sixth grade classroom in a suburban area outside of Portland, Oregon. Students were given a pre-test with questions on the rock cycle, rock types, and conservation of matter prior to the start of a two week unit to cover these three major concepts. One week after the pre-test students began the unit on the rock cycle and conservation of matter. 
After completing the unit, students were given a post-test and a delayed post-test to measure how the instruction shaped their knowledge on key concepts over time.

Student scores on the question about the law of conservation of matter were compared and analyzed statistically from pre-test to post-test to delayed post-test. Questions on the rock types and conservation of matter were compared to show the difference in learning gains on less complex subject area, such as rock types in contrast to more abstract and difficult to understand concepts of conservation of matter. Quantitative and qualitative findings were analyzed through the lens of a teacher, familiar with the students and their struggles and successes while learning about conservation of matter. 


\section{Literature Review}

Students are expected to learn the properties and changes of matter beginning in fifth grade according to the National Science Education Standards (NRC, 1996). However, recent research has shown that these are very difficult concepts for students to learn, particularly at the middle school level (Lempinen, 2010). Student understanding of foundational science concepts has a significant impact on their ability to master more difficult concepts as they progress from middle school into their high school years and beyond. As educators, we need to identify the best instructional strategies to teach the big ideas in science and to provide students with multiple opportunities to engage in meaningful learning across science disciplines.

The literature review will address two main areas related to how students learn about conservation of matter, a foundational concept in science and a key to student understanding of the properties and changes in matter. The first area addresses research studies designed around conservation tasks, a commonly used method for researching and studying student understanding of conservation of matter. The second area will focus on research studies about learning progressions and instructional recommendations specific to learning about conservation of matter in K-12 classrooms.

Conservation tasks test a child's ability to recognize that certain properties are conserved after an object, or a set of objects, undergoes a physical transformation (Gulko et al., 2001). Using conservation tasks, Piaget and Inhelder 
(1974) created a landmark study to show how students apply their skills and knowledge with regard to conservation of matter, mass, and volume. They concluded that children's success in performing conservation tasks was highly dependent on their cognitive development (Piaget \& Inhelder). Jean Piaget's four stages of cognitive development are: sensory motor from ages $0-2$, preoperational from ages 2-7, concrete operational from ages 7-12, and formal operations ages 12 and up. Through his experiments on conservation of matter, weight, and volume, Piaget found that children conserved matter earliest at 7 or 8 years of age, then weight at approximately 10 or 11 years, and volume at approximately 11 or 12 years (Piaget \& Inhelder).

Piaget and Inhelder (1974) were among the first to look closely at the ways in which children view the properties of matter. In one of their experiments, children were asked to predict what would happen to the weight and volume of water after sugar is dissolved in the water. Children aged 4-12 revealed many ideas including the idea that weight is not an intrinsic property of matter; matter can disappear; when matter disappears from sight, it no longer exists; and, physical changes are not viewed as reversible (Pyke \& Ochsendorf, 2004).

Through a variety of conservation tasks, Piaget and Inhelder found that children were able to conserve matter better at some ages than others, and often a child could perform some conservation tasks correctly but not others. Children also struggled to recognize reversibility of individual tasks. At times, the same child performed differently across learning contexts while performing similar 
types of conservation tasks. Through the results of many experiments, Piaget and Inhelder (1974) concluded that children's success in performing conservation tasks was dependent on their cognitive development, particularly if they had entered the concrete operational stage of cognitive development and demonstrated the ability to apply logic to individual tasks.

One of the critiques of Piaget and Inhelder's work included giving young children conservation tasks in which they were unfamiliar with objects and processes necessary for solving the task. For example, "Piaget and Inhelder's testing procedure presupposed knowledge of how a balance scale works, what it measures, how to measure volume in terms of displacement of water, and how to label the taste of sugar" (Au, Sidle \& Rollins, 1993, p. 287). Critiques of Piaget's work in the field on child development often had to do with the fact that his work failed to recognize multiple factors that affect a child's ability to process information and focused too narrowly and exclusively on the child's cognitive abilities.

In the 1990's many studies were designed after Piaget and Inhelder's work. Some of the studies that came after Piaget and Inhelder followed similar procedures and used the same conservation tasks; however, other researchers implemented revised methodologies, taking common critiques of their work into consideration. Au et al. replicated a well known task designed by Piaget and Inhelder, dissolving sugar into water to test children's ability to conserve matter. In their replicated study, Au et al. first taught children age 3-7 the vocabulary they 
needed to describe or explain what they saw, as well providing the participants with some basic background knowledge on measuring the mass of an object. This study yielded a higher number of children who were able to perform conservation tasks when provided with basic background knowledge. Children ages 3-5 showed the greatest improvement in their ability to conserve under the revised procedures with $69 \%$ showing correct responses in the revised group versus $45 \%$ in Piaget's original experiment (Au et al., 1993).

Stavy (1990) developed an important study examining how students learn about conservation of matter. Her study included first through ninth graders, 2025 students per grade in Israel. Students were given four tasks, one of which was evaporation of acetone and iodine in separate capped test tubes. Fifty percent of seventh graders understood the concept of conservation of matter as it changes phase through evaporation. This study concluded that children were able to solve some conservation tasks without being able to solve others. The responses children gave improved with age and experience, but not necessarily in a linear fashion (Stavy).

Based on the results of her 1990 study, Stavy returned in 1991 with a second study that looked at student understanding of evaporation with acetone and iodine, and two other conservation concepts. Stavy re-designed her original experiment by asking students to solve the iodine task first, followed by acetone. Results from her previous work suggested that students performed better on the iodine task than the acetone, primarily due to the fact that iodine has color and 
acetone is clear. The acetone evaporation task was more difficult for students to identify while the iodine evaporation showed the color of the gas as it evaporated, allowing students to identify the change in phase. Stavy (1991) gave students the less difficult iodine evaporation task first allowing them to be more successful at correctly identifying what happened with the acetone, a clear substance. "The intuitively understood, perceptually supported iodine task apparently served as an analogical example for the misunderstood acetone task" (Stavy, 1991, p. 310).

Stavy's 1991 study provided positive evidence for anchoring new content and complex tasks to intuitive and familiar concepts and ideas. Au et al. (1993) and Stavy $(1990,1991)$ yielded different results than those found by Piaget and Inhelder in 1974. Both Au et al. and Stavy determined that instruction and background knowledge, clear conservation tasks, and student perception and intuitive knowledge all play a part in students' abilities to conserve matter. While these three groups of researchers came to different conclusions about what age students would likely be able to perform the different conservation tasks, and differed in their approach to studying how students learn about conservation of matter, they were in agreement about how young children and school aged children acquired conservation skills and knowledge gradually over time.

Later studies created additional support for the findings that students acquire conservation skills gradually (Agung \& Schwartz, 2007; Gomez et al. 1995; Gulko et al. 2001; Haidar, 1997; Ozmen \& Ayas, 2003). Gulko et al. (2001) studied developmental patterns in conservation skills in 390 children, aged 4-11 
using the Goldschmid and Bentler Concept Assessment Kit. The matter tasks on the test included a task with clay and one with water. Their analyses revealed a relationship between conservation abilities and grade level. These results supported Piaget and Inhelder's (1974) work and contributed to the understanding of the development of concrete operational thought in children (Gulko et al., 2001).

In 2003, Ozmen \& Ayas conducted an international study with 10th grade students. They administered multiple-choice tests with questions about conservation of matter upon completion of a unit on chemical reactions. About half of 150 tenth graders showed an understanding of conservation of matter and chemical reactions, the other half held a number of misconceptions. Student misconceptions were found to be consistent and had many similarities across cultures. Ozmen and Ayas (2003) also observed the difficulties students face overcoming their misconceptions and naïve scientific ideas with traditional teaching methods. This study was significant in its contribution to the literature because it showed that similar difficulties and misconceptions in learning about conservation of matter are consistent internationally.

Gomez et al. (1995) examined four groups of adolescents age 12-17, and two groups of college students with varying levels of chemistry knowledge. The purpose of the study was to compare the representation of conservation of matter by subjects with different age and instructional levels in chemistry and to analyze how the context in which a task was presented influenced the activation of 
different conceptions (Gomez et al.). This study found that conservation of matter is less difficult for students to understand when applied to a physical change, such as change of state rather than a chemical reaction. Gomez et al. demonstrated the importance of connecting difficult concepts to familiar concepts, showing that students are more likely to have experience with changes of state and physical transformations of matter than chemical reactions.

Research by Haidar (1997) focused on the conceptions of prospective chemistry teachers and the way they teach students about conservation of matter. In this study, 173 prospective chemistry teachers were observed while teaching lessons on conservation of matter to measure their understanding and the understanding of their students after receiving instruction. Results suggested that prospective chemistry teachers have not developed an appropriate conceptual understanding of the conservation of matter and related concepts. The results also imply that more effective teaching methods need to be developed to help subjects develop meaningful learning as opposed to rote learning or memorization of concepts.

More recently, Agung and Schwartz (2007) studied 867 eleventh grade students in Indonesia. Students were given a 25 -item questionnaire, which when analyzed showed only $23 \%$ of students were able to answer the five questions on conservation of matter correctly. The purpose of the study was to look at conceptual understanding versus understanding of algorithms (stoichiometry and balancing chemical equations) used when teaching students concepts of 
conservation. Findings of this study were consistent with Stavy (1990) and Ozmen and Ayas (2003), as the majority of the students surveyed used personal models to answer conservation questions instead of applying the principles of conservation (Agung \& Schwartz). These results also demonstrated the difficulty students face when learning conservation of matter and related concepts, and how these difficulties follow them well into their high school years.

In summary, young children, school aged children, and adults have a difficult time learning conservation of matter, especially as it is applied to atomic molecular theory, and changes of matter. In order to learn about how students build an understanding of this difficult concept, many researchers have asked questions in the form of conservation concepts, which ask students to perform a task and answer questions about matter that has undergone a transformation, including some of the same tasks used in Piaget and Inhelder's foundational work (Au et al., 1993; Stavy, 1990; 1991). Other researchers used questionnaires, surveys and more traditional pencil and paper tests combined with semi-structured interviews (Agung \& Schwartz, 2007; Gomez et al.1995; Ozmen \& Ayas, 2003). Through a variety of questions and objectives, the research has confirmed conservation of matter is a difficult and important concept for students to learn.

Through an assortment of tasks and assessment tools, researchers have paved the path for the development of curriculum as well as providing a clearer picture as to how and where foundational concepts of matter fit into the larger context of learning progressions. These studies have also indicated the need for 
informed educators to design instruction that necessarily builds on student prior knowledge and their ability to progress into an understanding appropriate for where students are cognitively and developmentally.

Learning progressions (LP's) describe the potential for students to move toward a more advanced understanding of a big idea of science over a defined time period (Smith, Wiser, Anderson, \& Kracjik, 2006). Learning progressions have been developed from research, including the aforementioned studies, to provide educators with a road map to help students learn this foundational, yet difficult concept in science.

In their comprehensive review of the literature regarding how students learn about matter and atomic molecular theory, Smith et al. proposed a learning progression for these topics focused around six big ideas, one of which was the conservation of mass. For grades 6-8, Smith et al. (2006) suggested students should be able to understand that mass and weight (not volume) are conserved across chemical changes, dissolving, phase changes, and thermal expansion, and they should also be able to understand that in some transformations and changes materials may change appearance but the substances in them stay the same.

In 2007, Liu looked at how student understanding of matter grows and changes from elementary through high school as well as how understanding grows over the course of an academic year. Liu (2007) used an instrument called a "Progression of Understanding Matter" in elementary, junior high, and high school form. The test was administered to 536 Canadian students. They found 
differences in students' understanding of matter as grade level increased, showing that growth in students' concept development did not happen suddenly. "This may be due to the complexity and the unified nature of the concept. It shows that developing students' conceptual understanding of matter is a long-term effort" (Liu, 2007, p.1855). Liu proposed the need to teach matter using all aspects of conservation - physical properties and change, chemical properties and change, and composition and structure of matter starting as early as third grade. This study combined elements of developmental and cognitive psychology with science education research, and made important instructional recommendations central to providing students with the tools they need to build knowledge of conservation of matter over time.

Stevens, Delgado \& Krajcik (2010) used a construct-centered design (CCD) approach to create open-ended assessment tasks that measured student understanding of matter. The questions were incorporated into semi-structured interviews with individual students to characterize their understanding of topics related to matter. The participants were middle school and high school students. An analysis of student responses to the interview questions led to a Hypothetical Learning Progression (HLP). Recommendations for instructional strategies were provided to help move students along the HLP. For example, "students should only be introduced to new information when it is needed to explain a phenomenon or concept in order to make the new knowledge meaningful" (Stevens et al. 2010, p. 707). Stevens et al. recommended instruction focused on models and modeling 
to help students make connections between the macroscopic and atomic scale, and that instruction and assessments should focus on the connections across key concepts and ideas.

\section{Summary}

Despite Piaget and Inhelder's important studies on the ways in which children view properties and changes of matter, they focused on a very specific part of the child; their cognitive development. Since the time of Piaget and Inhelder's original work on the topic of students' understanding of matter at different ages, many research studies have expanded on cognitive development to include students' prior knowledge, or intuitive knowledge, how students learn about matter in different contexts, and how and where matter fits into the overarching curriculum. What is missing from the big picture is how students learn concepts of conservation of matter across disciplines in science.

Understanding the importance of providing learners with multiple opportunities and contexts to learn the big ideas in science, this study sought to gain understanding of the way students learn conservation of matter during a nonchemistry unit, and to add to the current body of research on learning progressions. This study also focused on the importance of teaching conservation of matter and related concepts to middle school students to help them develop a foundation of knowledge. The Benchmarks for Science Literacy (American Association for the Advancement of Science [AAAS], 1993), state that by the end of eighth grade students should know that: 
"No matter how substances within a closed system interact with one another, or how they combine or break apart, the total weight of the system remains the same. The idea of atoms explains the conservation of matter: If the number of atoms stays the same no matter how they are rearranged, then their total mass stays the same" (AAAS, 1993, p. 79).

In order to help students reach science literacy benchmarks and to become expert learners in science, an important first step is identifying how and when students should be learning concepts that show up year after year in the standards and determine ways in which to incorporate those concepts across the disciplines in science.

This research looks closely at the way sixth grade students build an understanding of conservation of matter during a non-chemistry unit. Research suggests that students need to be exposed to foundational concepts across disciplines with multiple opportunities to apply their knowledge and skills. This study works to provide specific examples of student understanding of a difficult concept when directly tied to less complex subject matter such as the rock types and the rock cycle. By examining student understanding of an important concept in science, educators can learn additional ways to make this concept more accessible to students while connecting difficult and complex concepts with their prior knowledge and experiences. If students are successful building a foundation of big ideas in science, they are more likely to be able to expand upon and apply their knowledge in different learning contexts across disciplines. 


\section{Method}

Overview

This study followed a mixed methods, quasi-experimental pre-post, delayed-post design. Students were given a pre-test with questions on the rock cycle, rock types, and conservation of matter prior to the start of a two-week unit to cover these three major concepts. One week after the pre-test students participated in an instructional unit on the rock cycle and conservation of matter, which was also the treatment in this study. Upon completion of the unit, students completed a post-test, and six weeks later took a delayed post-test. The purpose of administering the delayed post-test was to see if students understanding of conservation of matter would increase, decrease, or stay the same six weeks after the completion of the unit, and to help categorize students who either struggled or showed mastery in their learning about conservation of matter.

Quantitative data on student understanding from pre-test to post-test to delayed post-test was supported by qualitative data analysis. Qualitative data included an analysis of student responses to test questions, as well as formal and informal teacher observations of student understanding. Data gathered from classroom notes, observations, and daily teaching reflections were used to create three case studies of how students build an understanding of conservation of matter over time. The sequencing of the research design is shown in Figure 1. 


$$
\begin{array}{llll}
\mathrm{O}_{\text {pre }} & \mathrm{X} & \mathrm{O}_{\text {post }} & \mathrm{O}_{\text {dpost }}
\end{array}
$$

$\mathrm{O}_{\text {pre }}=$ Pre-test

$\mathrm{X}=$ Two weeks of instruction on the rock cycle, rock types, and law of conservation of matter

$\mathrm{O}_{\text {post }}=$ Post-test

$\mathrm{O}_{\text {dpost }}=$ Delayed post-test

Figure 1: Research design.

Portland State University Human Subjects Review Committee and the

Valley School District Research Application Coordinator reviewed and approved this research study (see Appendix F). Pseudonyms have been assigned to all participants (including the school and district).

Student scores on the question about law of conservation of matter were compared and analyzed statistically from pre-test to post-test to delayed post-test. Questions on the rock types and conservation of matter were compared to show the difference in learning gains on less complex subject area, such as the three main rock types, as opposed to more complex and difficult to understand concepts of conservation of matter.

\section{Participants}

Thirty $6^{\text {th }}$-grade students in an integrated science course offered at a suburban middle school outside Portland, Oregon participated in this study. Of those 30 students, 13 were female and 17 were male. Four students were on Individualized Education Plans (IEP's) and received special education services during the time the unit was taught. Eleven percent of the students at this middle 
school received special education services (SPED), 9\% were identified as English Language Learners (ELL), 28\% qualified for free and reduced lunch, and 12\% of the population participated in Talented and Gifted (TAG) programs.

As the researcher and student teacher I chose the first of three sixth grade science classes to participate in the research. This was also the most appropriate choice as I was working under the guidance of the regular classroom teacher and the instructors of the teacher education program at the university. Students returned signed parent permission slips (Appendix $G$ ) indicating their willingness to allow their child to participate in the research and to allow their child's assignments and test scores to be analyzed for the purposes of this study.

\section{Instruments}

The instruments used in this study were teacher-made tests, designed using Oregon State Science Standards and National Science Education Standards. In addition, the instruments were tied to unit objectives for the Valley School District and the curriculum for sixth grade science students at Happy Valley Middle School. Test questions were designed to probe student understanding on the rock cycle, rock types and law of conservation of matter using multiple choice and short answer response questions. All of the questions asked on the pre-test were included in the post-test with additional questions to address all of the content covered during the unit. The delayed post-test was composed of four short answer questions. Of the questions on the delayed post-test, there was one question on the rock cycle, one on conservation of matter, and two other related 
questions. All pre-test, post-test and delayed post-test included one short answer question asking students to state the law of conservation of matter as it relates it to the rock cycle.

The pre-test had a total of eight questions. All eight pre-test questions were included on the post-test along with an additional nine questions. The delayed post-test included only four questions that were taken from the concepts covered in the unit and included on the pre-/post-tests. This study looked closely at one main question from all three tests, which asked students to connect the law conservation of matter to the rock cycle (see Appendix C, D, and E for pre, post, and delayed post-tests).

The tests I used for this study were the regular assessments used to measure student understanding, and were designed to address the main concepts taught in the unit. I aligned the unit and tests with the school curriculum and district standards for sixth grade Physical Science and Earth Science as they related to the law of conservation of matter and the rock cycle. My cooperating teacher proofread all assessments before they were given to students. In addition to my cooperating teacher, my peers in the Portland State University Graduate Teacher Education Program informally evaluated and made suggestions to the tests I designed and used for teaching the unit.

\section{Procedure}

Students received a pre-test on concepts to be covered in the rock cycle unit with multiple choice and short answer questions. The pre-test was given one 
week prior to the start of the unit. Students then took part in the treatment, which was a series of lessons designed to teach students about key concepts of the rock cycle, rock types, and the law of conservation of matter. I was responsible for designing, teaching and assessing all lessons for this unit with directions and suggestions by my cooperating teacher. I used district curriculum recommendations and daily learning targets to guide my instruction and lesson planning at all times.

On the last day of the unit, students took the post-test with the same questions as the pre-test along with nine additional questions. Six weeks after the completion of the unit, students answered four short answer questions on the delayed post-test to measure their understanding over time and how they were able to retain the information on the main concepts covered in the unit.

Short answer responses to the question about the law of conservation of matter were scored using a rubric with specific criteria and given a point value of 0, 1, 2, or 3 (see Appendix B).

- $\quad$ A score of 3 demonstrated a full understanding of how the law of conservation of matter relates to the rock cycle. Student must have been able explain that matter cannot be created nor destroyed, but it changes form, just as rocks change from one rock type to another in the rock cycle.

- Example: "This law states that matter is neither created nor destroyed It is always changing, just like rocks in the rock cycle" (Student B).

- An answer given a score of 2 was missing a complete explanation of how conservation of matter is related to the rock cycle, but showed an understanding that matter is neither created nor destroyed.

○ Example: "New matter isn't created. Its only changed. like rocks they change to other rocks" (Student O). 
- A score of 1 showed a partial understanding of conservation of matter. A score of 1 had only one of the three main parts of the concept (i.e. matter cannot be destroyed).

○ Example: "That everything changes like in the rock cycle" (Student P).

- $\quad$ A score of 0 was given to students who did not give a response. Zeros were also given for incorrect use of key terms, incorrect responses, and incomplete responses.

○ Example: "Everything is matter" (Student L).

Another science teacher and myself scored all student responses to the short answer question on conservation of matter using a scoring rubric designed for this purpose (see Appendix B). Prior to having a conversation about the scoring, we had $70 \%$ inter-rater reliability as we scored 21 out of 30 responses the same. After a discussion and exchange of ideas about how we scored student responses independently, we agreed on 29 out of 30 responses, which brought our inter-rater reliability to $97 \%$.

The main reason for the difference in scoring between myself and the other science teacher was explained by the way I had scored student responses at different points in time. I had also made minor changes to the scoring rubric without going back and changing the students whose responses that had already been scored. The one question we disagreed on was missing a part of student understanding that matter changes form. After a discussion on this question, we were able to make our inter-rater reliability $100 \%$.

\section{Treatment}

The treatment was an instructional unit on the rock cycle and conservation 
of matter, which included unit objectives, daily lesson plans, and assessments aligned to State, National, and district science content standards for sixth grade. Goals and objectives for the unit included learning the differences between physical characteristics of sedimentary, igneous, and metamorphic rocks; describing and labeling a diagram of the rock cycle; understanding the law of conservation of matter as it applies to the rock cycle; explaining that rocks are always changing form through the rock cycle; and describing the different processes associated with the rock cycle.

The first day of the unit began with a hands-on grouping, sketching, and recording physical characteristics of rocks activity followed by a rock cycle diagramming activity. Major activities in the unit included two labs. The first lab was meant to demonstrate the concept of conservation of matter as it relates to the rock cycle. Students combined materials representative of the three types of rock, performed processes such as heating or applying force to change the materials, and made observations at the end of the lab explaining whether there was more, less, or the same amount of material (matter) than the amount they started with.

The second lab was a two-day activity that asked students to identify the three types of rocks after making observations about the types of materials the rocks were made of. For example, a conglomerate rock composed of different pebbles and sediments was a sedimentary rock caused by the compaction and cementation of broken down pieces of rock. The purpose of the rock identification lab was for students to make connections between physical properties of rocks, 
rock material and the three rock types using their observation skills. The labs were designed to help students connect their understanding of matter or rocks changing form as they explored the way different rocks can change form, but the amount of matter that exists is the same, even after rocks have been exposed to various processes through the rock cycle. Student work in this unit had an emphasis on literacy with two vocabulary activities and the creation of a foldable or book to compile all of the concepts and diagrams from the unit.

A typical day consisted of 75-minute instructional periods that began with a warm-up and discussion on a relevant topic for the day, or by reviewing an important concept from a previous lesson. The instructional time and activities would usually be divided into two or three separate segments in order to keep students engaged throughout the class period. The class would typically end with a self-assessment, formative assessment, or a closing discussion on what we had learned that day and why. Self-assessments often asked students to rate and reflect on their progress in meeting daily learning targets.

The instructional strategies used in the classroom were designed to have students actively engaged in the learning process through hands-on explorations, partner and group activities, and active participation in class discussions. Formative assessment was used on a daily basis to help guide instruction, and was one of the ways I was able to identity the need to study how students build an understanding of the important concept of conservation of matter.

The unit objectives were used to create assessments in a proficiency-based 
grading model recently adopted by the Happy Valley School District. Unit

objectives had been broken down into daily learning targets that were posted in a student friendly language on the white board each day. Unit objectives listed below (Table 1) were mapped to the unit overview, with daily lesson plans and objectives outlined in Table 2 .

Table 1: Unit Goals and Objectives

\begin{tabular}{|l|l|}
\hline $\begin{array}{l}\text { Learning } \\
\text { Target } \\
\text { LT): }\end{array}$ & Students will: \\
\hline LT 1.1 & $\begin{array}{l}\text { Learn the differences between the physical characteristics of } \\
\text { sedimentary, igneous, and metamorphic rocks. }\end{array}$ \\
\hline LT 1.2 & $\begin{array}{l}\text { Learn how sedimentary, igneous, and metamorphic rocks are formed } \\
\text { and what type of rock material they are made of. }\end{array}$ \\
\hline LT 1.3 & Describe, label and draw a diagram of the rock cycle. \\
\hline LT 1.4 & $\begin{array}{l}\text { Understand the Law of Conservation of Matter as it applies to the rock } \\
\text { cycle. }\end{array}$ \\
\hline LT 1.5 & $\begin{array}{l}\text { Explain different processes associated with the rock cycle such as } \\
\text { weathering and erosion, heat and pressure, and compaction and } \\
\text { cementation. }\end{array}$ \\
\hline LT 1.6 & $\begin{array}{l}\text { Develop and apply process skills in observing, describing, and } \\
\text { recording physical characteristics of igneous, sedimentary, and } \\
\text { metamorphic rocks. }\end{array}$ \\
\hline LT 1.7 & $\begin{array}{l}\text { Know the difference between constructive and destructive forces and } \\
\text { examples of each. }\end{array}$ \\
\hline LT 1.8 & Explain that rocks are always changing form through the rock cycle. \\
\hline
\end{tabular}

Table 2: Rock Cycle Unit Overview

\begin{tabular}{|c|c|}
\hline Day & Daily Lesson Plans and Objectives \\
\hline 1 & $\begin{array}{l}\text { Unit Introduction } \\
\text { - Learning Targets: } 1.1,1.3,1.6 \\
\text { - Students work in partners at their table groups to describe and sort rocks } \\
\text { by observable physical characteristics. } \\
\text { Class discussion on the three main rock types, their characteristics, and } \\
\text { an introduction to the rock cycle diagram and key vocabulary concepts. } \\
\text { How did your group decide to categorize the rocks you were given? } \\
\text { What words did you use to describe them? }\end{array}$ \\
\hline 2 & $\begin{array}{l}\text { Rock cycle exploration: Edible Rocks Lab } \\
\text { - Learning Targets: } 1.1,1.2,1.3,1.4,1.5 \\
\text { - Students will combine food materials that represent the three rock types } \\
\text { and perform processes in the rock cycle such as applying pressure, and } \\
\text { heat, allowing the materials to cool and breaking up sedimentary rocks } \\
\text { into sediments. } \\
\text { The goal is for students to relate the rock cycle (food materials) to the } \\
\text { law of conservation of matter. At the end of the processes, was there } \\
\text { more, less, or the same amount of matter (food materials)? Why? }\end{array}$ \\
\hline
\end{tabular}




\begin{tabular}{|c|c|}
\hline 3 & $\begin{array}{l}\text { - } \quad \text { Learning Targets: } 1.1,1.2,1.6 \\
\text { - } \quad \text { Review Edible rocks lab from previous day } \\
\text { - } \quad \text { Rock books pages } 1 \& 2 \text { : Igneous and sedimentary rocks. } \\
\text { - } \quad \text { Examples of each rock type for students to see and discuss with a } \\
\text { partner or small group. } \\
\text { - Students continue to build their vocabulary and refine their observation } \\
\text { skills and descriptions of the physical characteristics of the rock types. }\end{array}$ \\
\hline 4 & $\begin{array}{l}\text { Making Predictions and Observations } \\
\text { - } \quad \text { Learning Targets: } 1.2,1.3,1.5,1.6 \\
\text { - Weathering and Erosion slide show: Famous landforms and geologic } \\
\text { features formed by weathering and erosion. } \\
\text { - Video Clip: Bill Nye Rocks and Soil } \\
\quad \text { Rock cycle quiz: Students draw the rock cycle diagram with appropriate } \\
\text { labels and vocabulary. }\end{array}$ \\
\hline 5 & $\begin{array}{l}\text { Rock Books Pages } 3 \& \mathbf{4} \\
\text { - } \quad \text { Learning Targets: } 1.2,1.7 \\
\text { Students work independently on drawing and defining the difference } \\
\text { between constructive and destructive forces as they apply to the rock } \\
\text { cycle. Using their knowledge and experiences so far in the unit and the } \\
\text { examples of page } 1 \text { and } 2 \text { in their rock books, they also create a page on } \\
\text { metamorphic rocks }\end{array}$ \\
\hline $6 \& 7$ & $\begin{array}{l}\text { Rock Identification Lab } \\
\text { - Learning Targets: } 1.2,1.4,1.5,1.6,1.8 \\
\text { Students work in pairs at stations of rocks around the classroom. } \\
\text { Compare and contrast rock types, processes that form them, and how } \\
\text { that relates to the law of conservation of matter. Emphasis on how rocks } \\
\text { are changing from one rock type to another through the forces in the } \\
\text { rock cycle. }\end{array}$ \\
\hline 8 & $\begin{array}{ll} & \text { Learning Targets: } 1.3,1.6 \\
\text { - } & \text { Vocabulary application: Vocabulary concept cards } \\
\text { - } & \text { Rock Cycle Quiz 2 } 2^{\text {nd }} \text { attempt } \\
\text { - } & \text { Rocks books self and peer assessment activity } \\
\end{array}$ \\
\hline 9 & $\begin{array}{l}\text { History of Rock Activity } \\
\text { - } \quad \text { Learning Targets: } 1.1,1.2,1.5,1.6,1.8 \\
\text { Students are assigned to research an assigned rock in pairs or groups of } \\
\text { threes. Working together, they recreate the history of their rock using a } \\
\text { data sheet provided for them. } \\
\text { - Students become the experts in their rock type and teach the history of } \\
\text { their rock to the rest of the class in a 3-5 minute presentation. }\end{array}$ \\
\hline 10 & $\begin{array}{l}\text { Rock Cycle Review Game } \\
\text { - Learning Targets: } 1.3,1.5,1.6 \\
\text { - Students go to stations that are steps and processes in the rock cycle. A } \\
\text { kinesthetic activity to get students out of their seats and talking to each } \\
\text { other about the rock cycle as a review for the unit test. }\end{array}$ \\
\hline 11 & Unit Post-Test \\
\hline
\end{tabular}




\section{Results}

The aim of this mixed methods, quasi-experimental, pre-post-delayed post design study was to examine how students learn about the concept of conservation of matter during a unit on the rock cycle. The goal was not to establish a causal relationship between the instruction and student understanding, but to determine the difficulties and successes students encountered when learning this fundamental concept in science. By examining how 30 students built an understanding of conservation of matter and the rock cycle over time, this study can contribute to the growing body of literature relating to learning progressions and effective instructional techniques with the purpose of making a difficult concept more accessible to a wide range of learners.

Quantitative data collected in this study through pre-tests, post-tests and delayed post-tests were analyzed using two tailed $t$-tests and graphical representations of data. Qualitative data collected through teacher observations and student responses to pre-tests, post-tests, and delayed post-tests were analyzed by indexing and coding student responses, looking for trends, and reflecting upon and interpreting the data. Qualitative and quantitative data were used to measure variability in student test scores before, after, and six weeks after the unit on the rock cycle and conservation of matter.

\section{Pre-Post-Test Comparison on Rock Types and Conservation of Matter}

Pre-post and delayed post-tests were designed and intended to measure the level of student understanding on less difficult or less complex concepts such 
as the rock types, as well as more difficult concepts such as the law of conservation of matter. Question number 2 on the pre-/post test was a short answer question chosen to measure student understanding of the law of conservation of matter as it relates to the rock cycle. Questions 3, 4, and 5 on the pre-/post-tests were multiple-choice questions chosen to measure student understanding of the three main types of rock and how they are formed.

Students showed dramatic increases in learning gains from pre to post-test when asked about how the three rock types were formed as shown by Figure 2 and Table 3. Fewer students showed learning gains on the more difficult and complex concept of conservation of matter.

Table 3: Students who answered pre-test and post-test questions on rock types and conservation of matter correctly.

\begin{tabular}{|c|c|c|c|c|}
\hline \multirow[b]{2}{*}{ Question } & \multicolumn{2}{|c|}{ Pre-Test } & \multicolumn{2}{|c|}{ Post-Test } \\
\hline & $\begin{array}{l}\text { Students } \\
\text { with } \\
\text { Correct } \\
\text { Response } \\
N=\mathbf{3 0}\end{array}$ & $\begin{array}{l}\text { Students } \\
\text { with } \\
\text { Correct } \\
\text { Response } \\
\text { (\%) } N=\mathbf{3 0}\end{array}$ & $\begin{array}{l}\text { Students } \\
\text { with } \\
\text { Correct } \\
\text { Response } \\
N=\mathbf{3 0}\end{array}$ & $\begin{array}{l}\text { Students with } \\
\text { Correct } \\
\text { Response } \\
(\%) N=\mathbf{3 0}\end{array}$ \\
\hline $\begin{array}{l}\text { Q2: What does the "Law of } \\
\text { Conservation of Matter" } \\
\text { explain with regard to the } \\
\text { rock cycle? }\end{array}$ & 0 & $0 \%$ & 11 & $37 \%$ \\
\hline $\begin{array}{l}\text { Q3: Metamorphic rocks are } \\
\text { formed by } \\
\text { a) The cooling and } \\
\text { hardening of lava or } \\
\text { magma } \\
\text { b) Compaction and } \\
\text { cementation } \\
\text { c) Intense heat and pressure } \\
\text { and sometimes hot watery } \\
\text { liquids }\end{array}$ & 9 & $30 \%$ & 30 & $100 \%$ \\
\hline
\end{tabular}




\begin{tabular}{|c|c|c|c|c|}
\hline $\begin{array}{l}\text { Q4: Sedimentary rocks are } \\
\text { formed by } \\
\text { a) Intense heat and pressure } \\
\text { and sometimes hot watery } \\
\text { liquids } \\
\text { b) Compaction and } \\
\text { cementation of broken } \\
\text { down rock material } \\
\text { c) The cooling and } \\
\text { hardening of lava and } \\
\text { magma }\end{array}$ & 20 & $67 \%$ & 30 & $100 \%$ \\
\hline $\begin{array}{l}\text { Q5: Igneous rocks are } \\
\text { formed by } \\
\text { a) The cooling and } \\
\text { hardening of lava or } \\
\text { magma } \\
\text { b) Compaction and } \\
\text { cementation } \\
\text { c) Intense heat and pressure } \\
\text { and sometimes hot watery } \\
\text { liquids }\end{array}$ & 13 & $43 \%$ & 30 & $100 \%$ \\
\hline
\end{tabular}

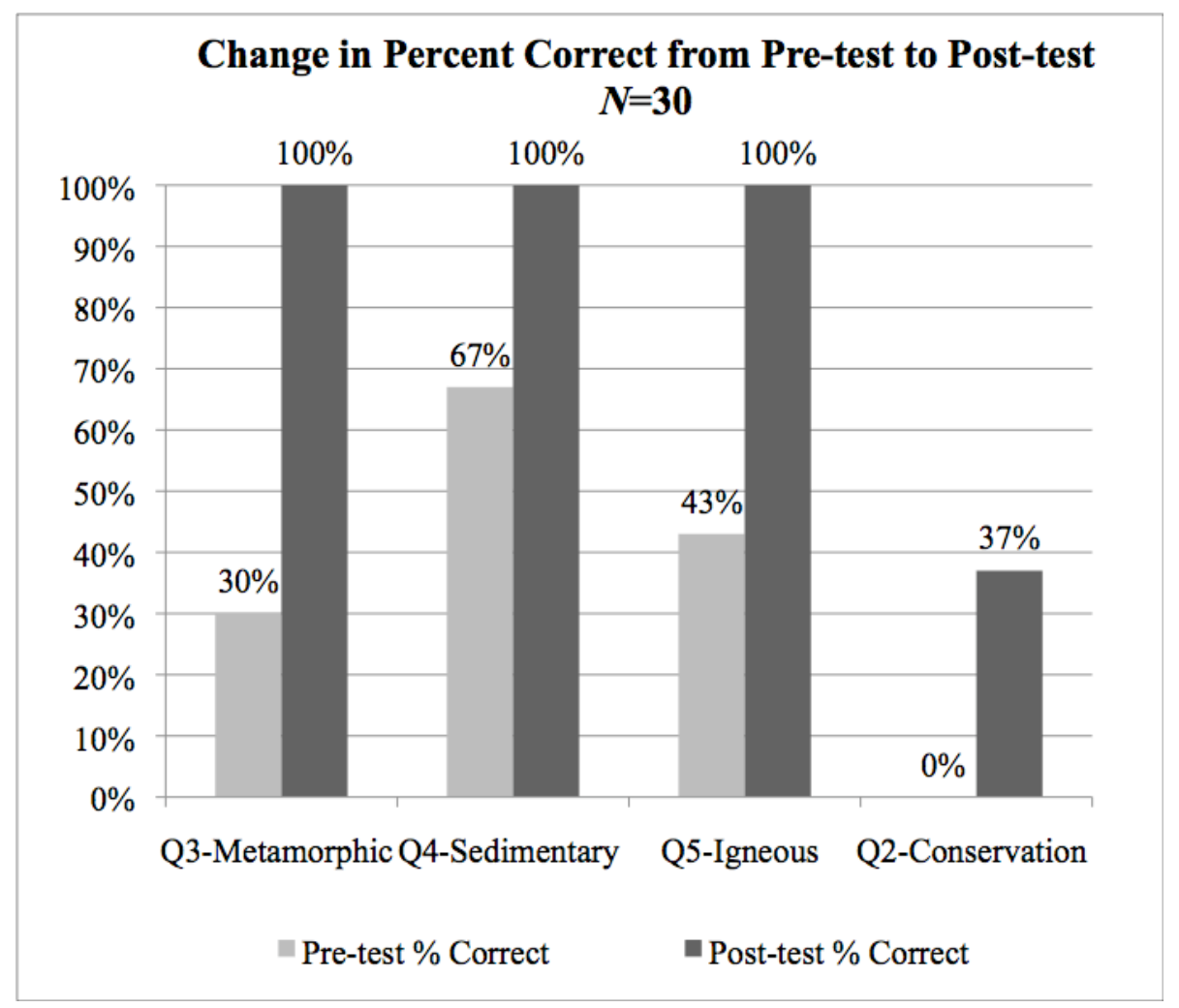

Figure 2: Comparison of correct answers on rock types and conservation pre-test to post-test for all 30 students. 
Table 3 and Figure 2 show that $100 \%$ of students answered each of the three rock type questions correctly on the post-test, which shows that students had greater difficulty learning the concept of conservation of matter compared to the rock types and their formation. They also show how students' scores were different when asked about different types of concepts. Even though it was clear that students had more difficulty learning about conservation of matter, 11 out of 30 , or $37 \%$ students demonstrated a full understanding of the concept.

The results from this comparison led to an interest in looking at why some students were able to demonstrate mastery in learning conservation of matter while others did not. There was also an interest in seeing how students who mastered the concept would retain that knowledge over time compared to students who struggled to learn the concept.

Pre-Post-Delayed Post-Test Comparison of Conservation of Matter

In order to gain a deeper understanding of how students build their knowledge on a difficult and important concept, conservation of matter, this study looked at student test scores before, after, and six weeks after participating in a unit on the rock cycle and conservation of matter. After analyzing the results of how students performed on questions about the rock types compared to conservation of matter, I turned my attention to student responses to the question about conservation of matter on the pre-post and delayed post-test.

Figure 2 shows the change in average scores for 24 out of 30 students when asked the question: "What does the "Law of Conservation of Matter" 
explain with regard to the rock cycle?" on all three tests. Due to the fact that six students chose not to participate in the delayed post-test, those students' pre-post test scores have been eliminated from the data anytime there is a comparison involving the delayed post-test scores.

Measures of statistical significance were determined using a two-tailed $t$ test. Student scores were found to be statistically significant from pre-test to posttest, and pre-test to delayed post-test as shown in Figure 2 and Table 4.

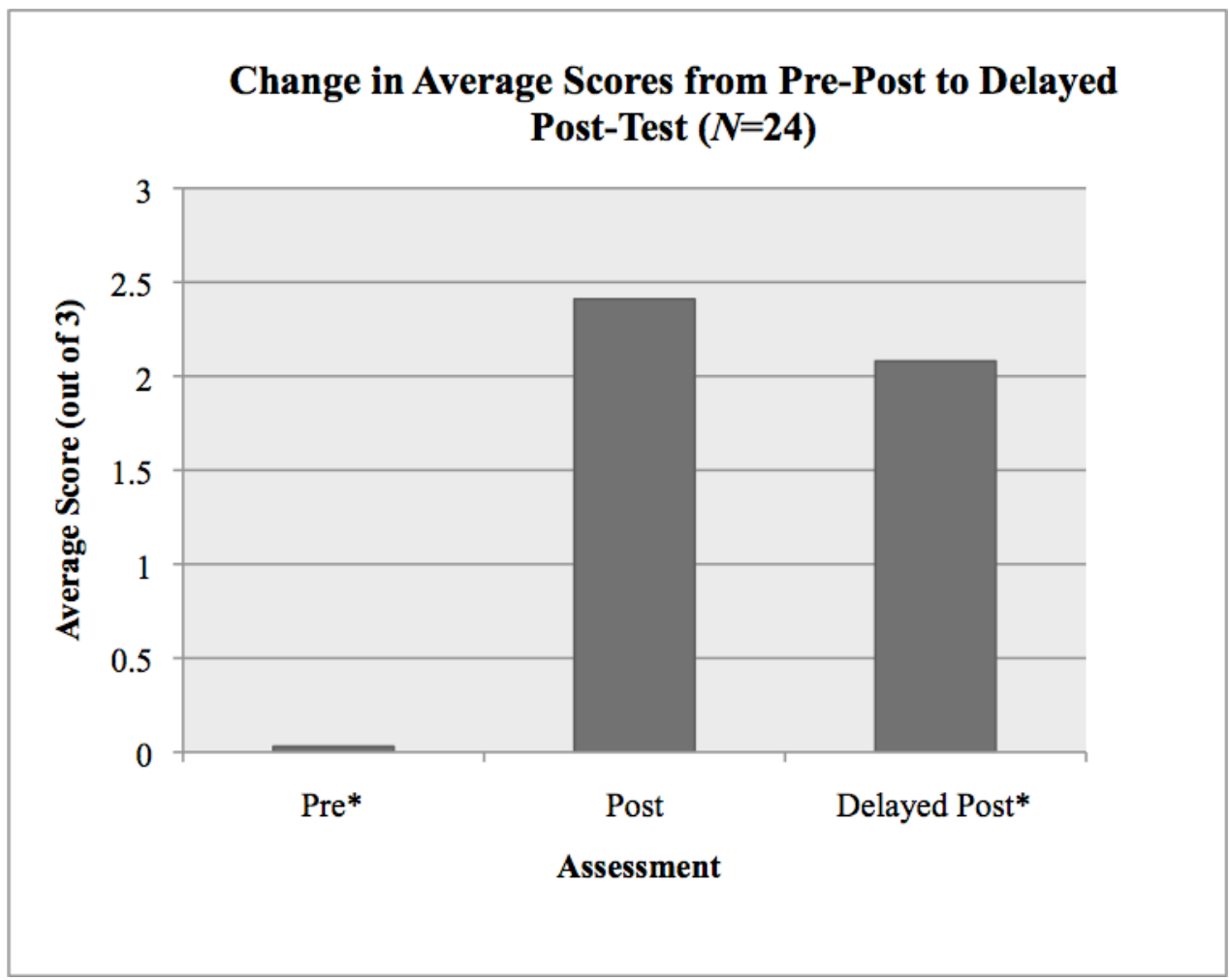

Figure 3: Change in average scores from pre-/post-test to delayed post-test on Question 2, relating to conservation of matter. The difference between pre-test scores and both the post-test and delayed post-test scores were statistically significant, $p<0.0001$. The difference between the post-test and delayed post-test scores were not statistically significant, $p=0.14$. 
Table 4: Measures of statistical significance from pre-/post-test to delayed posttest on conservation of matter.

\begin{tabular}{|l|l|l|}
\hline $\begin{array}{l}\text { *Pre-test to Post-test } \\
\text { Average Scores }\end{array}$ & $\begin{array}{l}\text { Post-test to Delayed } \\
\text { Post-test Average Scores }\end{array}$ & $\begin{array}{l}\text { *Pre-test to Delayed } \\
\text { Post-test Average Scores }\end{array}$ \\
\hline Statistically significant & $\begin{array}{l}\text { Not statistically } \\
\text { significant }\end{array}$ & Statistically significant \\
\hline p- value of 0.0001 & p-value of 0.14 & p-value of 0.0001 \\
\hline
\end{tabular}

The difference in average scores on the conservation question (Question 2) from post-test to delayed post-test was not statistically significant. Seventeen of the 24 students (71\%) scored the same or higher, indicating that most students did not lose their understanding over time.

How Students' Understanding of Conservation of Matter Changed

As the results from Figure 3 have shown, $71 \%$ of students scores stayed the same or increased from post-test to delayed post-test given six weeks later. In addition, previous results showed that many students had greater difficulty building an understanding of conservation of matter than less complex concepts such as the three main rock types and how they are formed. 


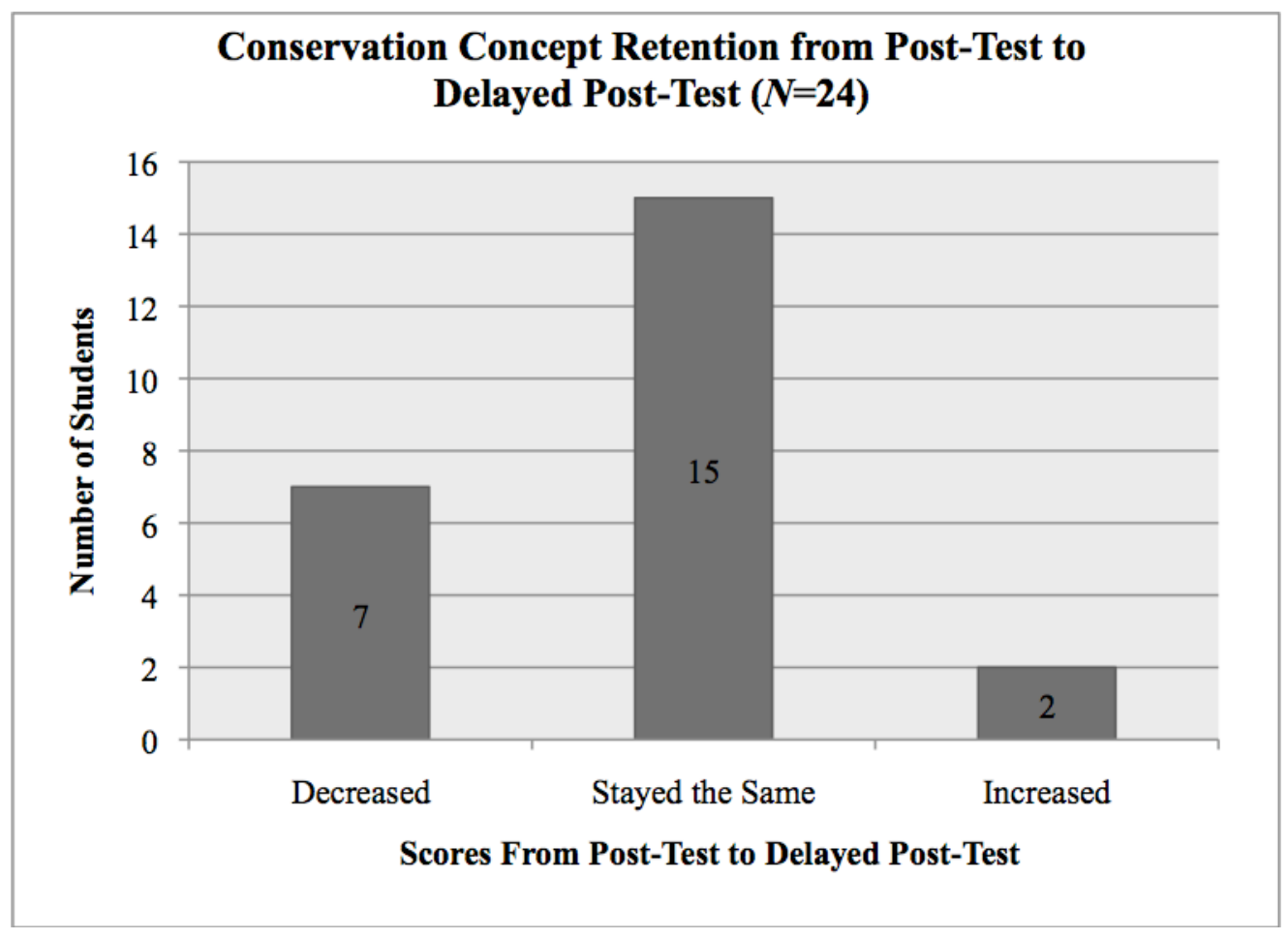

Figure 4: Change in scores from post-test to delayed post-test for 24 students.

Many students' scores stayed the same from post-test to delayed post-test as shown in Figure 4 and Table 5. These results, along with the results that showed 7 students had a decrease in scores and 2 students had an increase in their scores over time led to an interest in learning more about trends in student understanding. What were some of the common themes that emerged with groups of students who performed similarly? What can examining student responses tell us about their overall understanding of a difficult concept 
Table 5: Concept retention from post-test to delayed post-test: Students' understanding of conservation of matter and the rock cycle.

\begin{tabular}{|l|c|c|c|}
\hline & $\begin{array}{c}\text { Scores } \\
\text { Decreased from } \\
\text { Post-Delayed } \\
\text { Post }\end{array}$ & $\begin{array}{c}\text { Scores } \\
\text { Stayed the } \\
\text { Same from } \\
\text { Post-Delayed } \\
\text { Post }\end{array}$ & $\begin{array}{c}\text { Scores } \\
\text { Increased from } \\
\text { Post-Delayed } \\
\text { Post }\end{array}$ \\
\hline $\begin{array}{l}\text { Number of } \\
\text { Students } \\
\boldsymbol{N}=\mathbf{2 4}\end{array}$ & 7 & 15 & 2 \\
\hline $\begin{array}{l}\text { Percentage of } \\
\text { Students } \\
\boldsymbol{N}=\mathbf{2 4}\end{array}$ & $29 \%$ & $63 \%$ & $8 \%$ \\
\hline
\end{tabular}

Individual student scores and responses are included in Tables 6, 7, 8, 9,

and 10 showing their actual responses without editing, and whether or not they

increased, decreased, or stayed the same from post-test to delayed post-test.

Table 6: Students whose scores decreased from post- to delayed post-test

\begin{tabular}{|l|l|l|l|l|}
\hline $\begin{array}{c}\text { Student } \\
\text { Code }\end{array}$ & \multicolumn{2}{|c|}{$\begin{array}{c}\text { Post to } \\
\text { Delayed Post- } \\
\text { Test Scores }\end{array}$} & \multicolumn{1}{|c|}{ Post-Test Response } & \multicolumn{1}{c|}{$\begin{array}{c}\text { Delayed Post-Test } \\
\text { Response }\end{array}$} \\
\hline E & 2 & 0 & $\begin{array}{l}\text { Matter that can't neither be } \\
\text { destroyed nor built. It can } \\
\text { change form, }\end{array}$ & No answer. \\
\hline I & 3 & 2 & $\begin{array}{l}\text { So, the law of onservation of } \\
\text { matter is, matter is neither } \\
\text { created or destroyed. So when a } \\
\text { rock goes through the Rock } \\
\text { cycle, its type of rock changes, } \\
\text { but it is never destroyed. and it } \\
\text { doesn't create more Rock. }\end{array}$ & $\begin{array}{l}\text { Matter is neither created } \\
\text { or destroyed, so rocks } \\
\text { are neither created or }\end{array}$ \\
\hline destroyed
\end{tabular}


In order to help me understand why some students' scores had decreased from post-test to delayed post-test, I also looked at their scores on the rock types questions, the rock cycle diagram, and their final grade in science as shown in Table 7. I took into consideration that some students were highly motivated, yet it was the end of the year when even the most motivated students were tired and not trying as hard as they had earlier in the school year. By looking at other work students had completed over time, I noticed a trend suggesting students had much less difficulty learning about the rock types and the rock cycle than learning the law of conservation of matter, a foundational concept in science.

Table 7: A closer look at students whose scores decreased from post-test to delayed post-test.

\begin{tabular}{|l|l|l|l|c|}
\hline $\begin{array}{l}\text { Student } \\
\text { Code }\end{array}$ & $\begin{array}{l}\text { Rock Types } \\
\text { Pre-Post-Test } \\
\text { Scores } \\
\text { (Out of 3) }\end{array}$ & $\begin{array}{l}\text { Rock Cycle } \\
\text { Diagram Pre-Post } \\
\text { to Delayed Post- } \\
\text { Test Scores } \\
\text { (Out of 13) }\end{array}$ & $\begin{array}{l}\text { Conservation of } \\
\text { Matter Pre-Post } \\
\text { to Delayed Post- } \\
\text { Test Scores } \\
\text { (Out of 3) }\end{array}$ & $\begin{array}{l}\text { Final } \\
\text { Grade } \\
\text { in } \\
\text { Science: }\end{array}$ \\
\hline P & 0,3 & $0,13,13$ & $0,2,1$ & $\mathrm{~A}$ \\
\hline Z & 2,3 & $0,13,13$ & $0,2,0$ & $\mathrm{~A}$ \\
\hline BB & 3,3 & $0,13,13$ & $0,3,1$ & $\mathrm{~A}$ \\
\hline J & 1,3 & $0,13,13$ & $0,3,2$ & $\mathrm{~A}$ \\
\hline I & 1,3 & $0,13,13$ & $0,3,2$ & $\mathrm{~A}$ \\
\hline W & 0,3 & $0,12,2$ & $0,2,1$ & $\mathrm{C}+$ \\
\hline E & 2,3 & $0,13,0$ & $0,2,0$ & $\mathrm{~A}$ \\
\hline
\end{tabular}

Students who had a decrease in scores from post-test to delayed post-test appear to have shown mastery in less difficult concepts such as identifying the rock types and creating a diagram of the rock cycle. Out of seven students whose scores decreased, there were five who scored $100 \%$ on the rock cycle and the rock types on the post-test and the delayed post-test. The two students who showed a decrease on the rock cycle in addition to the conservation of matter question had 
also shown an overall lack of interest in learning near the end of the school year.

Sixty-three percent of the students maintained the same scores on the posttest and delayed post-test, and as seen in Table 8 , almost all of those students scored 2's and 3's on their responses, suggesting a trend in student understanding and concept retention over time. Many students who showed a strong understanding on the post-test also showed a strong understanding six weeks after the unit was taught.

Table 8: Students who scored the same from post-test to delayed post-test.

\begin{tabular}{|l|l|l|l|l|}
\hline $\begin{array}{c}\text { Student } \\
\text { Code }\end{array}$ & \multicolumn{2}{|c|}{$\begin{array}{c}\text { Post to } \\
\text { Delayed Post- } \\
\text { Test Scores }\end{array}$} & \multicolumn{1}{|c|}{ Post-Test Response } & \multicolumn{1}{c|}{$\begin{array}{c}\text { Delayed Post-Test } \\
\text { Response }\end{array}$} \\
\hline B & 3 & 3 & $\begin{array}{l}\text { This law states that matter is } \\
\text { neither created nor destroyed It } \\
\text { is always changing, just like } \\
\text { rocks in the rock cycle. }\end{array}$ & $\begin{array}{l}\text { It states that nothing is } \\
\text { either created or } \\
\text { destroyed, but it is } \\
\text { always changing, just } \\
\text { like rocks in the rock } \\
\text { cycle. }\end{array}$ \\
\hline D & 2 & 2 & $\begin{array}{l}\text { It's the fact that no matter is } \\
\text { made or destroyed only } \\
\text { changes form. }\end{array}$ & $\begin{array}{l}\text { It means no new matter } \\
\text { is made or destroyed it } \\
\text { only changes }\end{array}$ \\
\hline F & 3 & 3 & $\begin{array}{l}\text { The law of conservation of } \\
\text { matter means matter is neither } \\
\text { created nor destroyed. Like in } \\
\text { the rock cycle the rocks are not } \\
\text { destroyed or created just } \\
\text { changing form. }\end{array}$ & $\begin{array}{l}\text { The law of conservation } \\
\text { of matter is that no } \\
\text { matter is destroyed or } \\
\text { made just changing. } \\
\text { This relates to the rock } \\
\text { cycle because over time } \\
\text { rock is only changed. }\end{array}$ \\
\hline $\mathrm{G}$ & 3 & 3 & $\begin{array}{l}\text { Matter is neither created or } \\
\text { destroyed. Rocks are not } \\
\text { destroyed or created just } \\
\text { changed. }\end{array}$ & $\begin{array}{l}\text { Rocks never get } \\
\text { destroyed or created } \\
\text { just changed. } \\
\text { matter is made and no matter is } \\
\text { destroyed it just changes }\end{array}$ \\
\hline 3 & 3 & $\begin{array}{l}\text { The law of conservation } \\
\text { of matter refers to how } \\
\text { no new matter is } \\
\text { created or destroyed. In } \\
\text { the rock cycle no new } \\
\text { matter is made or } \\
\text { destroyed, just changed. }\end{array}$ \\
\hline
\end{tabular}




\begin{tabular}{|c|c|c|c|c|}
\hline $\mathrm{M}$ & 2 & 2 & $\begin{array}{l}\text { Matter (or in this case, rocks) is } \\
\text { not created or destroyed. }\end{array}$ & $\begin{array}{l}\text { The law of conservation } \\
\text { of matter is the law that } \\
\text { new matter is not made, } \\
\text { and matter is not } \\
\text { destroyed. This ties in } \\
\text { with the rock cycle } \\
\text { because no new rocks } \\
\text { are made or destroyed. }\end{array}$ \\
\hline $\mathrm{S}$ & 0 & 0 & All rock are made of minerals & $?$ \\
\hline $\mathrm{T}$ & 3 & 3 & $\begin{array}{l}\text { That matter is neither created } \\
\text { nor destroyed, but it changes in } \\
\text { form just like the rock cycle but } \\
\text { instead of matter, rocks. }\end{array}$ & $\begin{array}{l}\text { It means matter is } \\
\text { neither created nor } \\
\text { destroyed and its like } \\
\text { the rock cycle because } \\
\text { that's rock does it in } \\
\text { this case the matter. }\end{array}$ \\
\hline $\mathrm{O}$ & 2 & 2 & $\begin{array}{l}\text { New rocks arnt made they are } \\
\text { only changed }\end{array}$ & $\begin{array}{l}\text { New matter isn't } \\
\text { created. Its only } \\
\text { changed. like rocks they } \\
\text { change to other rocks }\end{array}$ \\
\hline $\mathrm{X}$ & 3 & 3 & $\begin{array}{l}\text { Matter is neither made or } \\
\text { destroyed. Rocks are never } \\
\text { destroyed, they change form } \\
\text { over time }\end{array}$ & $\begin{array}{l}\text { Matter cannot be } \\
\text { destroyed or builded. } \\
\text { (there can never be new } \\
\text { rocks or rocks that can } \\
\text { be eliminated) A rock } \\
\text { always come back in } \\
\text { different forms }\end{array}$ \\
\hline A & 2 & 2 & $\begin{array}{l}\text { That rocks never get destroyed } \\
\text { they just change. }\end{array}$ & $\begin{array}{l}\text { That nothing ever } \\
\text { disappears it just } \\
\text { changes. Like when } \\
\text { rock erodes from water } \\
\text { it mixs with the water } \\
\text { to make salt water. Or } \\
\text { when lava and water or } \\
\text { cold gasess, air. }\end{array}$ \\
\hline AA & 3 & 3 & $\begin{array}{l}\text { Matter is neither created nor } \\
\text { destroyed, only changes form. } \\
\text { A rock goes through many } \\
\text { processes but its matter always } \\
\text { stays the same, the rock only } \\
\text { changes form. }\end{array}$ & $\begin{array}{l}\text { Matter is neither } \\
\text { created or destroyed, it } \\
\text { only changes form. A } \\
\text { rock goes through many } \\
\text { forms but its matter } \\
\text { stays the same }\end{array}$ \\
\hline $\mathrm{Y}$ & 3 & 3 & $\begin{array}{l}\text { Matter is not made or } \\
\text { destroyed. the rock cycle } \\
\text { doesn't make or destroy rocks, } \\
\text { it just changes them }\end{array}$ & $\begin{array}{l}\text { Law of conservation of } \\
\text { matter: matter is neither } \\
\text { created or destroyed... } \\
\text { this connects to the rock } \\
\text { cycle because in the } \\
\text { rock cycle matter is not } \\
\text { made or destroyed... it } \\
\text { is changed }\end{array}$ \\
\hline $\mathrm{K}$ & 2 & 2 & $\begin{array}{l}\text { No new matter is made and no } \\
\text { matter that already exists can be } \\
\text { destroyed }\end{array}$ & $\begin{array}{l}\text { No new matter is added } \\
\text { or destroyed }\end{array}$ \\
\hline
\end{tabular}




\begin{tabular}{|l|l|l|l|l|}
\hline $\mathrm{V}$ & 2 & 2 & $\begin{array}{l}\text { It means that you cant destroy } \\
\text { matter, only change its form } \\
\text { kind of like you cant change } \\
\text { matter (rocks) but you can } \\
\text { change their form (like } \\
\text { sedimentary to metamorphic) }\end{array}$ & $\begin{array}{l}\text { Matter can not be } \\
\text { destroyed or built. You } \\
\text { can not build rocks or } \\
\text { destroy. Always matter. }\end{array}$ \\
\hline
\end{tabular}

The results show $93 \%$ of students whose scores stayed the same from post-test to delayed post-test scored either a 2 or a 3 on conservation of matter showing a strong understanding. Only one student out of 15 scored a zero and stayed at a zero, suggesting that students who had a full understanding of conservation of matter on the post-test were more likely to retain that information six weeks after participating in the unit.

Table 9: Students who scored higher on the delayed post-test than the post-test.

\begin{tabular}{|l|l|l|l|l|}
\hline $\begin{array}{c}\text { Student } \\
\text { Code }\end{array}$ & \multicolumn{2}{|c|}{$\begin{array}{c}\text { Post to } \\
\text { Delayed Post- } \\
\text { Test Scores }\end{array}$} & \multicolumn{1}{|c|}{ Post-Test Response } & \multicolumn{1}{|c|}{$\begin{array}{c}\text { Delayed Post-Test } \\
\text { Response }\end{array}$} \\
\hline Q & 2 & 3 & $\begin{array}{l}\text { No new rocks are made they } \\
\text { just change in form }\end{array}$ & $\begin{array}{l}\text { New matter is never } \\
\text { made or destroyed it is } \\
\text { reused just like the rock } \\
\text { cycle }\end{array}$ \\
\hline DD & 2 & 3 & $\begin{array}{l}\text { Law of conservation of matter } \\
\text { is neither created or destroyed }\end{array}$ & $\begin{array}{l}\text { The law of conservation } \\
\text { of matter means the rock } \\
\text { can be changed by forces } \\
\text { but nothing is being } \\
\text { made new or destroyed }\end{array}$ \\
\hline
\end{tabular}

\section{Students Who Did Not to Participate in Delayed Post-Test}

The delayed post-test was optional for students and not included as part of their grade in science. Only six students chose not to take the delayed post-test, which included a short answer question on the conservation of matter as it relates to the rock cycle, their answers on the post-test are outlined in Table 10. Of the six students who did not participate in the delayed post-test, four of them had received zeros on the pre-test and the post-test. Of the four students who received 
zeros on both the pre-test and the post-test, three of them were on Individualized Education Plans (IEP's) for learning disabilities.

Table 10: Scores of students who did not participate in the delayed post- test.

\begin{tabular}{|l|l|l|l|}
\hline Student & \multicolumn{2}{|l|}{ Pre- to Post Scores } & Post-Test Response \\
\hline C & 0 & 2 & No matter is destroyed nor created \\
\hline N & 0 & 2 & $\begin{array}{l}\text { Matter neither builds or destroys but } \\
\text { change all the time. Rocks neither build or } \\
\text { destroy but change all the time }\end{array}$ \\
\hline L & 0 & 0 & Everything is matter \\
\hline U & 0 & 0 & $\begin{array}{l}\text { Rocks are always going through the rock } \\
\text { cycle. Constructive forces and destructive } \\
\text { forces destroys rocks }\end{array}$ \\
\hline CC & 0 & 0 & Destructive forces and constructive forces \\
\hline R & 0 & 0 & A rock \\
\hline
\end{tabular}

Three out of four students in my class who had Individualized Education Plans (IEP's) had specific learning disabilities (students U, L, and R). The fourth student had a physical disability for writing, and performed extremely well on the post-test and delayed post-test, showing mastery in the concepts taught during the rock cycle unit. All three students with learning disabilities declined to take the delayed post-test. All three also had difficulty showing mastery on less complex concepts such as the rock types and the rock cycle, in addition to more complex concepts such as conservation of matter.

\section{Qualitative Data Analyzing Three Students' Understanding of Conservation of Matter From Beginning to End of the Unit}

Looking at how students were able to retain their knowledge of conservation of matter and identifying trends in student understanding among smaller groups of students led to a qualitative analysis of student responses from post-test to delayed post-test. In order to identify trends that may have contributed 
to student successes as well as what struggles students faced, I analyzed results from three students and how they developed an understanding of conservation of matter. Students highlighted in Table 11 represent one high, one medium and one low achieving student. In addition to their scores on tests and assignments, I analyzed my classroom notes and daily reflections, as well as my informal observations of student participation and behavior during class discussions and activities.

Table 11: Three students' scores on three different concepts over time.

\begin{tabular}{|l|l|l|l|c|}
\hline $\begin{array}{l}\text { Student } \\
\text { Code } \\
\text { High, } \\
\text { Medium, } \\
\text { Low }\end{array}$ & $\begin{array}{l}\text { Rock } \\
\text { Types: } \\
\text { Pre-post- } \\
\text { test } \\
\text { (Out of 3) }\end{array}$ & $\begin{array}{l}\text { Rock Cycle } \\
\text { Diagram: } \\
\text { Pre-post, } \\
\text { delayed } \\
\text { post-test } \\
\text { (Out of 13) }\end{array}$ & $\begin{array}{l}\text { Conservation } \\
\text { of Matter: } \\
\text { Pre-post, } \\
\text { delayed post- } \\
\text { test } \\
\text { (Out of 3) }\end{array}$ & $\begin{array}{l}\text { Final Grade } \\
\text { in Science: }\end{array}$ \\
\hline T (High) & 1,3 & $1,13,13$ & $0,3,3$ & $\mathrm{~A}+$ \\
\hline K (Med) & 1,3 & $0,13,13$ & $0,2,2$ & $\mathrm{~B}$ \\
\hline W (Low) & 0,3 & $0,12,2$ & $0,0,0$ & $\mathrm{C}$ \\
\hline
\end{tabular}

Student T was typical of the majority of students in this class. Student T performed very well on everything we did in science class before, during and after the rock cycle unit. He gave thoughtful written responses to the daily warm-ups, which were not graded, but also participated well and often during class discussions. This student continued to show a strong desire to learn and a strong interest in science, even in the final days of the school year when other students started to lose motivation. In addition, I observed this student as emotionally and socially mature for his age and someone who knew how to ask for clarification when he needed it.

Student K was someone whose scores surprised me at times. This student 
appeared to have a strong understanding in some areas of science, yet inconsistent in her efforts to learn and complete assignments. At times this student seemed unusually tired for a 12 year old. I made note of this as a concern in one of my written reflections. Student K was a student whose overall skill level was enough to get good grades without trying very hard. She came across as disengaged or bored, as well as tired. This person did not participate often in class discussions, but would occasionally participate if it was a topic that was of particular interest to her. I had two separate conversations with this student during the rock cycle unit to see if there was something I could do to help her stay focused during class and to have more success with completing labs and assignments, but this student still showed very little follow through. This student was average in her overall achievement, but still managed to get a " $\mathrm{B}$ " in the class. I think this had to do with this students' ability to learn and to do well, but not enough to show mastery. This person did not turn in one of the labs for the unit, but she did turn-in all other assignments. Her assignments were often done just well enough to get credit, but usually did not consist of exemplary work, or the type of work this student was capable of doing. I believe her inconsistency in completing class assignments and activities had a negative impact on her ability to build a strong understanding of conservation of matter.

Student W struggled in this unit in a number of different ways. This was not a student who had a learning disability or any known problems that would explain his low performance during the rock cycle unit. This student stood out to 
me due to his poor attitude and lack of interest in learning. This was one of the students who struggled more and more as the end of the school year approached. Student $\mathrm{W}$ rarely participated in class discussions and did not often complete the written portion of the daily warm-ups. This student also struggled with work completion and managed to turn-in only a few assignments during the course of the rock cycle unit. Among the missing assignments were the two lab activities, and the rock book, which students worked on for several days in class since it was not assigned as homework. This student was someone I considered to be performing at a very low level and therefore had a lack of confidence in science class. I feel as though his lack of participation during lab activities and daily class discussions had a great impact on his ability to learn the difficult concept of conservation of matter and how it relates to the rock cycle.

After looking closely at the overall understanding of key concepts for three students, one high, one medium, and one low achieving student, I can identify patterns that help me understand why some students were able to show mastery in learning about conservation of matter while others were not. When designing activities for this unit, I tried to include every student while creating challenging and engaging assignments and hands-on activities that would reach a diverse group of learners. Some activities were more difficult for students, including the rock identification lab.

Looking back at my class notes and written reflections for teaching the unit, I noticed that many students had trouble on the second day of the rock 
identification lab, which also explains why many students, especially those with overall grades of B's and C's were missing this assignment. Asking students to engage in a challenging activity for two days in a row seemed effective for some students, but certainly not all. I observed a decrease in student motivation and interest level on day two of this particular lab. Due to the decrease in motivation I observed, on day two of the rock identification lab we had a class discussion to clarify what I wanted to class to learn from this activity, and what I would like them to focus on. Despite having this conversation, many students were still confused and frustrated, even after addressing specific criteria and doing examples together as a class. This told me that perhaps students were confused and I should go back and re-teach some of the main concepts using a different approach. At that time, I created the History of a Rock assignment for students to trace the history of a particular rock. We used the same rocks as were used in the rock identification lab. This was helpful to most students. However, students W and $\mathrm{K}$ were both absent on the day we clarified the difficult concepts from the rock identification lab. I felt as though these two students could have benefited greatly by taking part in this activity. Their absences on the day of re-teaching and clarifying a two day lab activity may have had a negative impact on their overall attitude and understanding during the rock cycle and conservation of matter unit.

As the classroom teacher I observed and made informal assessments every day, and it is largely through these informal observations of students that I was able to learn how and why some students were so much more successful than 
others. Examining three students through a combination of my informal observations and their performance on pre-post and delayed post tests, as well as class activities and participation shows how three students were able build an understanding of conservation of matter. In addition to their ability to connect their knowledge of the rock types, the rock cycle, and conservation of matter, students' attitudes, motivation, work ethic, and interest in science also play a role. However, these are all difficult to measure, so it is useful to measure student responses to questions over time in combination with daily observations and patterns in individual student behavior.

In examining how students learn less difficult concepts compared to more difficult concepts; how students' understanding of a difficult concept changes over time; and how sub-categories of students show trends in understanding of a difficult concept; I have thought a great deal about how and why some students were more successful than others. In turn, I have thought about ways in which I can have a greater impact on student understanding, and to be able to contribute to existing body of research on how students build an understanding of conservation of matter during a non-chemistry unit. 


\section{Discussion}

The purpose of the study was to gather information about how students learn the foundational concept of conservation of matter during a non-chemistry unit on the rock cycle. I hypothesized that providing students with an opportunity to learn conservation of matter by connecting it to less complex content area, the rock cycle, it would help them learn the more complex and difficult concept of conservation of matter.

\section{Research Question}

\section{How do middle school students build an understanding of conservation of matter during a two-week unit on the rock cycle?}

This study followed a mixed methods, quasi-experimental pre-post, delayed post-test design. The participants were 30 students from a sixth grade classroom in a suburban area outside of Portland, Oregon. Students were given a pre-test with questions on the rock cycle, rock types, and conservation of matter prior to the start of a two-week unit to cover these three major concepts.

Student scores on the three separate tests were determined by using a scoring rubric with specific criteria and a scale of 0 to 3 (see Appendix B). When coding the data an important consideration had to be made in comparing pre-test and post-test scores to the delayed post-test scores because there were only 24 out of 30 scores available for the delayed post-test. During quantitative data analysis the six students who had no score available for the delayed post-test were eliminated from the data sets. When comparing pre-test to post-test learning 
gains, all 30 students scores were used to determine statistical significance since scores were available for all 30 students. A qualitative analysis was done on three students; one high, one medium and one low achieving student, to see how their performance in the class either contributed to or took away from their ability to understand a difficult concept.

The research design and methodology were selected because of their alignment with the purpose and goals of the study. The researcher measured what students knew prior to the unit being taught, what they knew at the end of the unit, and what knowledge and understanding they had retained six weeks after receiving instruction on the rock cycle and conservation of matter.

The results of this study began with a comparison of student answers to questions on the rock types and a question on the law of conservation of matter as it relates to the rock cycle. The results shown in Figure 1 reveal a clear difference in the way students performed from pre- to post-test when asked multiple choice questions on the rock types compared to a short answer question asking them to connect their understanding of conservation of matter to the rock cycle. Eleven of 30 students showed a full understanding of conservation of matter on the post-test while 30 out of 30 showed a full understanding of the rock types on three separate questions. The results from students' ability to understand a difficult concept when compared to a less complex concept is consistent with what Piaget and Inhelder (1974) found after conducting experiments on student ability to understand conservation of matter, weight, and volume. 
Piaget and Inhelder (1974) found that students were able to conserve matter at approximately age 7 or 8 , and their entrance into the concrete operational stage of cognitive development increased the likelihood that children would be able to apply logic and abstract thinking to a variety of conservation tasks. According to Piaget's work on the cognitive development of children, by the time children reach the age of 12 they are moving past the concrete operational stage toward formal operations stage. However, the way children progress from one stage of cognitive development to the next depends on many factors other than the age of the child. This has been one of the critiques of Piaget's work, though most cognitive psychologists and developmental psychologist acknowledge the work of Piaget as highly influential in the area of teaching and learning.

Acknowledging differences in the way students responded to the questions on rock types in comparison to the question on the law of conservation of matter was one of the drivers behind this research study. As a student teacher working with sixth graders, I often noticed how some students would struggle with concepts that required them to think more abstractly. I attributed this difference in achievement to the maturity level and individual differences in students' physical, emotional and cognitive development. Though it was not every student who struggled to learn complex concepts, I made this observation repeatedly while working with students of this age group. My observations were consistent with Piaget's stages of cognitive development. This observation and others led me to 
thinking about how I could tailor my instruction to fit the unique developmental needs of my students.

As a student teacher I was asked to teach the unit on the rock cycle and to combine it with the core concept of conservation of matter. It was through this assignment that I began to realize the importance of teaching foundational concepts across disciplines in science. In thinking about teaching core concepts across disciplines, I began to hypothesize that students who were able to connect their understanding of the rock cycle and conservation of matter would be more successful at mastering the content and retaining that knowledge weeks after the unit was taught.

In analyzing student average scores from pre-test to delayed post-test, my findings reinforced what I observed in the classroom. As the teacher and researcher, I was aware that many students were struggling to learn the concept of conservation of matter during the first few days of instruction. Students had no difficulty learning how to create a diagram of the rock cycle, just as they had no difficulty learning the rock types and how they are formed, which is consistent with my observations as the teacher. Again, this is one of the main reasons I became interested in looking at why students struggled to learn the concept of conservation of matter. There appeared to be an inconsistency amongst the students in my classroom in the way they were able to acquire knowledge and skills of complex concepts in science.

When I examined Figure 3, which shows the change in average student 
scores from pre-post, to delayed post-test, I noticed approximately one third of the students who participated in the study were able to show mastery on the concept of conservation of matter. Of the students who were able to show mastery, many were also able to retain their knowledge over time. This led to questions about individual student performance and trends in the way students were able to connect their understanding of conservation of matter to the rock cycle.

Additional questions arose when I analyzed the results shown in Figures 2 and 3. For example, what happened to students who were unable to show mastery in their understanding of the law of conservation of matter? Did students who established clear connections with the rock cycle learn the concept of conservation of matter and retain that information better over time? Looking at how students were able to retain their knowledge of conservation of matter led to further analysis of student responses from post-test to delayed post-test in order to identify trends that may have contributed to student successes as well trying to identify common struggles students experienced while learning this difficult concept.

After analyzing the results of student responses to the test questions on conservation of matter over time, I found that students who connected their understanding of the rock cycle to conservation of matter were more successful in grasping this difficult concept, and more likely to retain their knowledge six weeks after their participation in the unit. Results of student responses from posttest to delayed post-test questions on conservation of matter showed that nine out 
of 14 students whose scores stayed the same from post to delayed post-test scored 3 out of 3 , and then scored 3 on the delayed post-test. Those nine students had written explanations that showed mastery in their understanding of conservation of matter as it relates to the rock cycle. Not only did these students master the content, they retained that knowledge and understanding better over time than students who were unable to make important connections between the rock cycle and conservation of matter upon completion of the unit.

The following student responses are excerpts from Table 8. The excerpts focus on students who scored a 3 on both the post-test and the delayed post-test. These student responses were chosen to demonstrate the findings that students who connected conservation of matter to the rock cycle showed mastery in their concept development as well as in their ability to retain that knowledge six weeks after the unit commenced.

- The law of conservation of matter means matter is neither created nor destroyed. Like in the rock cycle the rocks are not destroyed or created just changing form.

- Matter is neither created nor destroyed, only changes form. A rock goes through many processes but its matter always stays the same, the rock only changes form.

- This law states that matter is neither created nor destroyed It is always changing, just like rocks in the rock cycle.

- Matter is neither created nor destroyed, only changes form. A rock goes through many processes but its matter always stays the same.

As the teacher and researcher in the classroom, I had the advantage of being able to use my observations of student behavior throughout the course of 
the unit. I also had the benefit of having relationships with each one of the students who participated in this study. The four students whose responses are highlighted here were four of the highest achieving students in the class, so not surprisingly, these students showed mastery in their ability to understand conservation of matter as it relates to the rock cycle. These particular students made a strong connection between the less complex concept of the rock cycle and the more difficult and complex concept of conservation of matter, and showed a higher level of maturity compared to their classmates. Maturity level and level of interest in science may have also contributed to their ability to show mastery and retain knowledge over time. It is possible that students who achieved particularly well in this unit and demonstrated a strong understanding of a difficult concept were farther along in the concrete operational stage of cognitive development as described by Jean Piaget.

In addition to examining the scores of students whose results were high and stayed high, I came across several students who caught my attention for very different reasons. One of the trends or patterns I recognized were very bright students who didn't take tests and assignments seriously, but showed mastery in their understanding through class discussions and activities. I was only able to observe this trend through my everyday interactions with students, but my observations were supported by the growth or lack of growth that students showed in their understanding of key concepts throughout the course of the unit. Informal observations of student understanding included, but were not limited to, the 
conversations between my students and myself, and conversations between groups of students.

Another pattern I saw existed among students who were very high achieving throughout the rock cycle unit who had lost motivation by the last week of school when the delayed post-test was given. Of particular concern was the trend I noticed among three of four students on Individualized Education Plan's (IEP's), who had all received zeros on their responses to the question on conservation of matter on the post-test. All three students on IEP's for specific learning disabilities also chose not to take the delayed post-test. This raises a lot of questions about the best ways to reach students of all abilities and backgrounds in the classroom so that each student has an opportunity to become an expert learner and an opportunity to become successful in learning key concepts in science. While a comprehensive discussion about how to differentiate for students of all abilities is beyond the scope of this paper, it is certainly an important consideration for any educator working in today's highly inclusive and diverse classrooms. It is not easy to differentiate instruction, but it is necessary. This study seeks to answer questions about how students build an understanding of a difficult concept in science, and in doing so works to create a better foundation for all students so they may build on those concepts over time, regardless of where their skill levels are when they enter into the classroom.

In addition to the students who showed mastery throughout, struggled throughout, or their understanding stayed the same, two students out of $24(8 \%)$ 
scored higher on the delayed post-test than on the post-test. This was an interesting finding since I had predicted that student scores would decrease on the same question after six weeks had passed. I predicted students would forget some of the details of their understanding or revert to their previous conceptions about changes in matter. However, the two students listed in Table 9 went from a full understanding of the law of conservation of matter to a full understanding of how it connects to the rocks in the rock cycle after six weeks. The unit that came after the rock cycle unit was ecosystems. Students revisited the rock cycle and conservation of matter when they learned about ecosystems including how the water cycle, chemical and physical changes, and living and non-living things impact ecosystems. Many students need time to make important connections in science, along with multiple opportunities to learn the same concept in different contexts, and the ability to explore and ask questions. It is possible the two students who showed an increase in scores from post to delayed post-test needed additional time to process their understanding and to connect this knowledge with other key concepts.

The purpose of the study was to gather information about how students learn the foundational concept of conservation of matter during a non-chemistry unit on the rock cycle. After analyzing the understanding of 30 sixth grade science students, I found that learning context plays an important role, which is in line with the findings of Stavy (1991) and Au et al. (1993). However, my observations as a teacher have led me to suggest that where students are developmentally plays 
an equally important role, particularly during young adolescence. In a sense this conclusion aligns with Piaget's work on cognitive development, but my experiences as a teacher and a researcher lead me to believe that where students are physically, emotionally, and socially are equally as important to consider as their cognitive abilities.

The findings of this study can build upon what is already known about how students learn the concept of conservation of matter. The results were consistent with many studies that have already been done in this area, but none of the existing research studies have focused on the way students learn conservation of matter during a non-chemistry unit. If we are to learn more about how students transfer their knowledge of conservation of matter across disciplines, more studies need to teach this core concept in multiple subjects at the same grade level, such as biology and chemistry, or chemistry and earth science. Findings and results of this study may lead to future studies designed to confirm the need to teach key concepts across the disciplines in science.

\section{Limitations}

This study was not without limitations. One of the main limitations was in the design of the questions asked on the pre-post, and delayed post-tests. As a novice teacher, I designed questions primarily based on the unit objectives given to me by the school and my cooperating teacher. The questions asked students to connect their understanding of the rock cycle to their understanding of conservation of matter, but the questions were not aptly designed to answer my 
research question about how students build their understanding of conservation of matter during a two-week unit on the rock cycle. The questions I designed and used to help me teach the unit only probed students on their level of concept comprehension. I needed questions that asked students to go from comprehension to application. Furthermore, I needed questions that asked students to apply their knowledge in more than one discipline of science.

Past researchers asked questions requiring students to apply their knowledge to scenarios and conservation tasks, as well as pencil and paper questions, many of which addressed common misconceptions at the same time they measured student knowledge and understanding (Agung \& Schwartz, 2007; Gulko et al. 2001; Haidar, 1997; Ozmen \& Ayas, 2003; Stavy, 1990; 1991). Knowing this, I returned to the literature to help me create a series of questions that would help me reach my goal in learning about how students build an understanding of conservation of matter. Looking at common student misconceptions and the various types of questions past researchers had used to study how students learn this concept, I came up with a series of questions to be used by science educators when teaching a unit on the rock cycle and conservation of matter.

According to Pyke \& Ochsendorf (2004), common misconceptions about matter include:

- When something happens to an object (expanding) the same thing happens to the thing that makes up the object (the object expands).

- Weight is not conserved in a reaction in which gas is absorbed or evolved, especially invisible gases.

- Gas is not a substance and does not have weight. 
- Chemical changes involve the disappearance and appearance of substances.

- Volume is directly related to mass (the more volume an object has, the greater its mass).

By designing questions that intentionally address commonly held

misconceptions among science students, we can gain a deeper understanding of

the ways students build an understanding of a complex concept. Also, how do

students who are successful in building foundational knowledge in science

progress in their understanding of science across disciplines as compared to those

who have not reached a full understanding of core concepts? More research needs

to be done in order to address these important questions.

Table 12: Recommended questions to use when teaching a unit on the rock cycle and conservation of matter.

\begin{tabular}{|c|c|}
\hline Question: & $\begin{array}{l}\text { Misconception Addressed or } \\
\text { Type of Assessment: }\end{array}$ \\
\hline $\begin{array}{l}\text { When a given sample of lava (molten } \\
\text { rock from a volcano) cools and becomes } \\
\text { solid, does it have more mass, less mass, } \\
\text { or the same amount of mass as when it } \\
\text { was in a liquid state? } \\
\text { Explain your answer. }\end{array}$ & $\begin{array}{l}\text { Misconception addressed: } \\
\text { Volume is directly related to mass (the } \\
\text { more volume an object has, the greater its } \\
\text { mass). } \\
\text { Assessment: } \\
\text { Students should be able to explain that } \\
\text { igneous rocks in both solid and liquid } \\
\text { form have the same mass. In other words, } \\
\text { no mass is lost or gained as the sample } \\
\text { changes form from molten rock to solid } \\
\text { rock. }\end{array}$ \\
\hline $\begin{array}{l}\text { When a given sample of sedimentary rock } \\
\text { is heated and put under great pressure so } \\
\text { it is changed into a metamorphic rock, } \\
\text { does it have more mass, less mass or the } \\
\text { same amount of mass than when it was a } \\
\text { sedimentary rock? }\end{array}$ & $\begin{array}{l}\text { Misconceptions addressed: } \\
\text { Volume is directly related to mass (the } \\
\text { more volume an object has, the greater its } \\
\text { mass). When something happens to an } \\
\text { object the same thing happens to the thing } \\
\text { that makes up the object. } \\
\text { Assessment: } \\
\text { Students may think that heat and pressure } \\
\text { would make a rock more massive. They } \\
\text { should be able to explain that the amount } \\
\text { of matter doesn't change when forces act } \\
\text { on sedimentary rocks transform them into } \\
\text { metamorphic rocks. }\end{array}$ \\
\hline
\end{tabular}




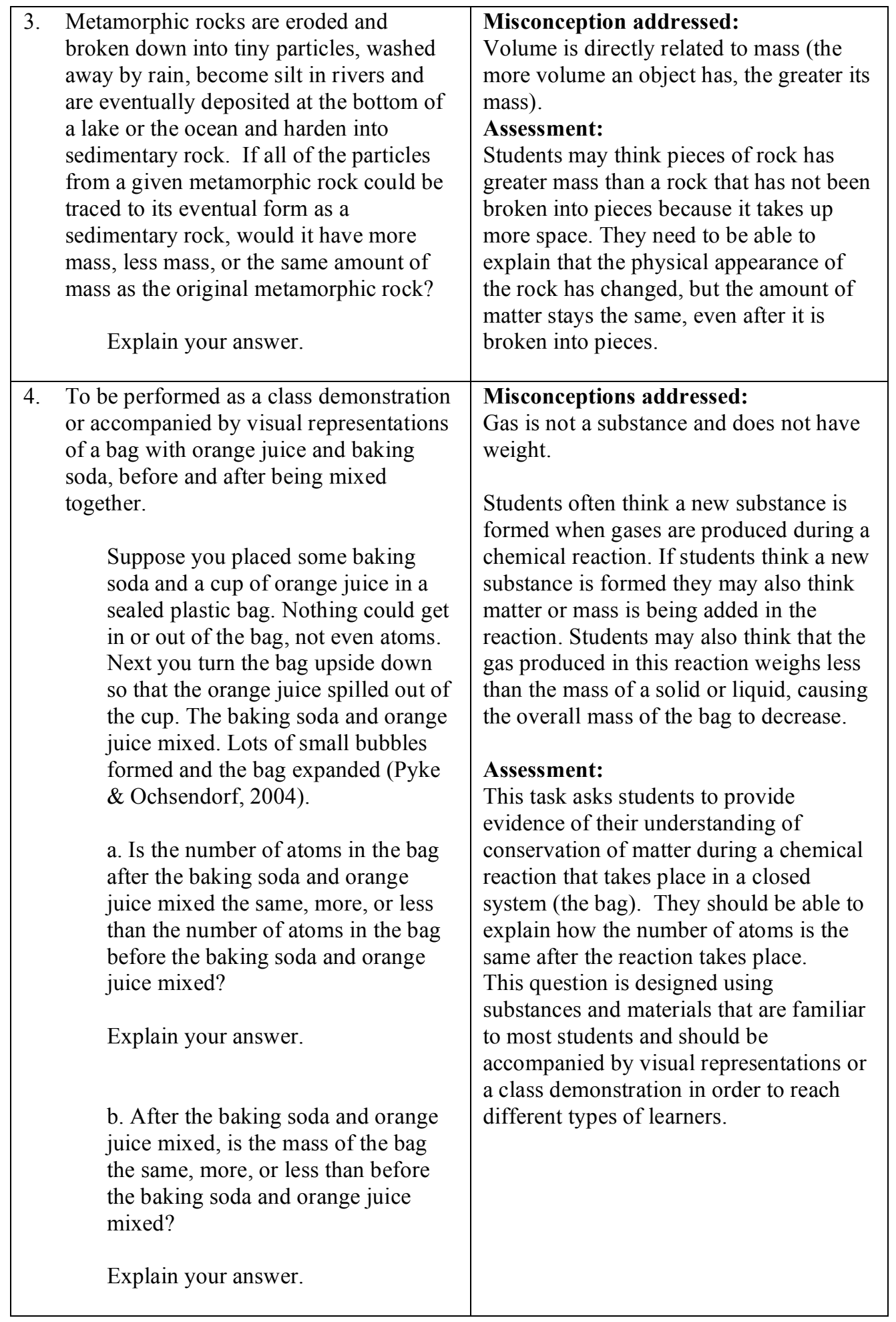




\begin{tabular}{|c|c|c|}
\hline & $\begin{array}{l}\text { To be performed as a class demonstration. } \\
\text { Suppose you have two glasses; one is } \\
\text { tall and skinny and one is short and } \\
\text { wide. Water is poured into each } \\
\text { glass. Which glass has more water? } \\
\text { Explain your answer. }\end{array}$ & $\begin{array}{l}\text { Misconception addressed: } \\
\text { Volume is directly related to mass (the } \\
\text { more volume an object has, the greater its } \\
\text { mass). } \\
\text { Assessment: } \\
\text { The tall skinny glass gives the appearance } \\
\text { of a greater amount of liquid. They } \\
\text { should be allowed to measure the mass of } \\
\text { each glass after they have written down } \\
\text { their initial predictions about which } \\
\text { container has more water. }\end{array}$ \\
\hline & $\begin{array}{l}\text { To be accompanied by pictures of the } \\
\text { sealed tubes, one with liquid water in it, } \\
\text { one without. May also be performed as a } \\
\text { class demonstration. } \\
\text { One gram of water is sealed in a } \\
\text { strong tube. The tube and the water } \\
\text { together weigh } 25 \text { grams. The tube } \\
\text { was heated until all of the water boils } \\
\text { and it is no longer visible. How much } \\
\text { will the sealed tube weigh now? } \\
\text { (Agung \& Schwartz, 2007). } \\
\text { a. Less than } 25 \text { grams } \\
\text { b. } 25 \text { grams } \\
\text { c. } 26 \text { grams } \\
\text { d. More than } 26 \text { grams }\end{array}$ & $\begin{array}{l}\text { Misconception addressed: } \\
\text { Weight is not conserved in a reaction in } \\
\text { which gas is absorbed or evolved, } \\
\text { especially invisible gases. Students often } \\
\text { describe evaporation of liquids as the } \\
\text { apparent disappearance of a substance. } \\
\text { Assessment: } \\
\text { The goal is to assess students' ability to } \\
\text { conserve matter after a phase change has } \\
\text { taken place. This question also addresses } \\
\text { the difficulty some students have when } \\
\text { asked to identify clear substances } \\
\text { compared to substances that have color. }\end{array}$ \\
\hline & $\begin{array}{l}\text { What is the law of conservation of matter } \\
\text { and how does it relate to the rock cycle? } \\
\text { Please provide an example using one or } \\
\text { more of the processes involved in the } \\
\text { rock cycle (compaction and cementation, } \\
\text { heating and cooling of magma or lava, } \\
\text { heat and pressure, weathering and } \\
\text { erosion). }\end{array}$ & $\begin{array}{l}\text { Assessment: } \\
\text { Students should be able to connect their } \\
\text { understanding of the law of conservation } \\
\text { of matter to their knowledge of the rock } \\
\text { cycle and rock types through a specific } \\
\text { example of one of the processes in the } \\
\text { rock cycle. The purpose of this question } \\
\text { is to get students thinking about how } \\
\text { different concepts overlap and build on } \\
\text { one another in science as well as to } \\
\text { demonstrate their understanding of both } \\
\text { the law of conservation of matter and the } \\
\text { rock cycle. }\end{array}$ \\
\hline
\end{tabular}

Future work in this area would benefit by incorporating key elements of

the experiments carried out by Stavy. The results from Stavy's work in 1990

informed her 1991 study, and led her to a better design that enabled her to answer

a very important and focused question about the way students build an 
understanding of conservation of matter. Through these two studies, Stavy determined that the order in which conservation tasks are presented to students had an impact on whether or not they can successfully perform the task. This idea was combined with the understanding that students will be able to solve tasks involving familiar objects, in familiar contexts while using tasks designed to connect with students' intuitive knowledge.

In addition to future work that builds on Stavy's $(1990,1991)$ research studies about how students learn conservation of matter, more work needs to be focused on the ways in which students learn this concept across disciplines in science. Does the opportunity to learn key concepts in different disciplines science have a positive effect on their ability to master difficult concepts?

Future studies that wish to focus on students' ability to master difficult concepts develop a series of questions and assessment tools similar to the Conservation of Matter Assessment (COMA) manual written by Pyke and Ochsendorf (2004). This assessment manual was designed in response to the research and the understanding that conservation of matter is an important and difficult concept for students to learn. The questions outlined in the COMA manual are specifically designed to probe for a deep understanding of the AAAS (1993) conservation of matter benchmark as compared to a question that only probes the surface level or asks for a definition. Question 4 of Table 12 is an example of the type of question found in the COMA manual. This manual also includes rating category descriptions to score student constructed responses. All 
of the questions in the COMA manual are designed to address common student misconceptions about changes in matter and atomic structure. The COMA manual is an excellent resource for teachers whose goal is to help their students become successful in their understanding of conservation of matter.

In addition to designing questions that probe for deep understanding and common misconceptions, assessments should strive to be developmentally appropriate. While it is important to understand how students of all age groups build an understanding of key concepts, close attention should be paid to young adolescents because of their rapid developmental and cognitive changes, and the importance of the foundational knowledge that students are expected to gain at this age (Carnegie Council on Adolescent Development, 1989). If students age 10-14 are not given developmentally appropriate curriculum designed to connect them with their prior knowledge in science, and provided with multiple opportunities to learn difficult concepts across disciplines in science, students may not be able to grasp more difficult concepts as they progress to high school and college.

As a student involved in the Robert Noyce Scholarship program at Portland State University, I intend to use the experiences and understandings that have come from this research study to inform my teaching practice. As a novice teacher it is extremely difficult to engage in best practices at all times no matter how great your intentions are. During my time teaching this unit and others, I often wished I could have done more for my students, or could have been clearer 
in my expectations, or could have spent more time doing hands-on activities. In retrospect the most valuable experience of all is to take time each day to reflect on your lessons. As I sat and reflected on my daily lessons, I thought about what I did to differentiate for the unique learners in my classroom, what worked and what could have been better. My reflections serve as guides for the next opportunity to teach the content, but to do it with more confidence and to be very intentional about what I want students to learn.

Working closely with the standards during the Noyce program came as an advantage in my student teaching. I knew how to unpack standards into daily and weekly learning targets and to always make that information available to my students. My students had the benefit of knowing each day what the learning goals were and how I was going to assist them in getting there.

Another advantage that came out of the Noyce program as well as the Graduate Teacher Education Program came from my knowledge and understanding of common student misconceptions in science. As I began to design my lesson plans for each instructional unit, I would go to the literature and identify common student misconceptions in that content area and teach with awareness of those misconceptions. I often found that student misconceptions were a fascinating source of information for me, and that I could use that information to keep me from reinforcing existing misconceptions or adding to the number of misconceptions my students walked away with.

As a pre-service teacher I am acutely aware that I will not be able to do 
everything I wish to do for my students every day of the school year. However, as a person who has a desire to do my best and to continue in the process of refining and growing my skills and practice, I know I will be able to inspire and help students see the value of science learning, and to assist students in the fun and exciting discoveries that middle school science. 


\section{References}

American Association for the Advancement of Science (1993). Benchmarks for Scientific Literacy. New York: Oxford University Press.

Agung, S., \& Schwartz, M. S. (2007). Students understanding of conservation of matter, stoichiometry and balancing equations in Indonesia. International Journal of Science Education, 29(13), 1679-1702.

Au, T.K., Sidle, A. L., \& Rollins, K. B. (1993). Developing an intuitive understanding of conservation and contamination: Invisible particles as a plausible mechanism. Developmental Psychology, 29(2), 286-299.

Carnegie Council on Adolescent Development (1989). Turning Points: Preparing American Youth for the $21^{\text {st }}$ Century. The Report of the Task Force on Education of Young Adolescents. New York: Carnegie Corporation of New York.

Gomez, M., Pozo, J., \& Sanz, A. (1995). Students' ideas on conservation of matter: Effects of expertise and context variables. Science Education, 79(1), 77-93.

Gulko, J., Doyle, A., Serbin, L. A., \& White, D. R. (2001). Conservation skills: A replicated study of order of acquisition across tasks. Journal of Genetic Psychology, 149, 425-439.

Haidar, A. H. (1997). Prospective chemistry teachers' conceptions of the conservation of matter and related concepts. Journal of Research in Science Teaching, 34(2), 181-197.

Lempinen, E. M. (2010, August 9). AAAS's Project 2061 Begins Effort to Develop New Middle School Materials for Chemistry, Biochemistry. In News Archives. Retrieved September 14, 2010, from http://www.aaas.org/news/releases/2010/08092061_grant.shtml.

Liu, X. (2007). Elementary to high school students' growth over an academic year in understanding the concept of matter. Chemical Education Research, 84(11), 1853-1856.

National Research Council. (1996). National Science Education Standards. Washington, D.C.: National Academy Press.

Ozmen, H., \& Ayas, A. (2003). Students' difficulties in understanding of the law 
of conservation of matter in open and closed-system chemical reactions. Chemistry Education: Research and Practice, 4(3), 279-290.

Piaget, J., \& Inhelder, B. (1974). The child's construction of quantities. London: Routledge \& Kegan Paul.

Pyke, C., \& Ochsendorf, R. (2004). Conservation of Matter Assessment Manual. Unpublished manuscript, The George Washington University.

Smith, C. L., Wiser, M., Anderson, C. W., \& Krajcik, J. (2006). Implications of research on children learning for standards assessment: A proposed learning progression for matter and the atomic molecular theory. Measurement, 14 (1\&2), 1-98.

Stavy, R. (1990). Pupil's problems in understanding conservation of matter. International Journal of Science Education, 12(5), 501-512.

Stavy, R. (1991). Using analogy to overcome misconceptions about conservation of matter. Journal of Research in Science Teaching, 28(4), 305-313.

Stevens, S. Y., Delgado, C., \& Krajcik, J. S. (2010). Developing a hypothetical multi-dimensional learning progression for the nature of matter. Journal of Research in Science Teaching, 47(6), 687-715. 


\section{Appendix A: Coding of Question 2 on Pre-Post and Question 1 on Delayed Post Test}

\section{A. Pre-Test}

Question 2: What does the "Law of Conservation of Matter" explain with regard to the rock cycle?

3 Points: Full Understanding of Law of Conservation of Matter and the rock cycle

2 Points: Full Understanding of Law of Conservation of Matter

\section{Points: Partial Understanding of Law of Conservation of Matter}

- I think that it has to do with nothing can be completely destroyed, It changes like in the rock and water cycle

0 Points: No answer or uncodable

- I don't know $=1$

- $\quad$ no answer $=29$

\section{B. Post-Test}

Question 2: What does the "Law of Conservation of Matter" explain with regard to the rock cycle?

3 Points: Full Understanding of Law of Conservation of Matter and the rock cycle.

- This law states that matter is neither created nor destroyed. It is always changing, just like rocks in the rock cycle.

- Matter is not made or destroyed. The rock cycle doesn't make or destroy rocks, it just changes them.

- Matter is neither created or destroyed. Rocks are not destroyed or created just changed

- That matter neither is created or destroyed, but it changes in form just like the rock cycle, but instead of matter, rocks.

- Matter is neither created nor destroyed, only changes form. A rock goes 
through many processes but its matter always stays the same, the rock only changes form.

- So, the law of conservation of matter is, matter is neither created or destroyed. So when a rock goes through the rock cycle, its type of rock changes, but it is never destroyed, and it doesn't create more rock.

- $\quad$ Rock do not get destroyed or created, they change.

- Matter that can't neither be destroyed nor built. It can change form,

- matter is neither made or destroyed. rocks are never destroyed, they change form over time

- The law of conservation of matter means matter is neither created nor destroyed. Like in the rock cycle the rocks are not destroyed or created just changing form.

- During the rock cycle no new matter is mad and no matter is destroyed it Just changes

- The law of conservation means that no new matter can be created nor destroyed. It can just be changed. Just like in the rock cycle, rocks are constantly changing.

\section{Points: Full Understanding of Law of Conservation of Matter}

- You cannot create or destroy matter It changes form

- It means that you cant destroy matter, only change its form kind of like you cant change matter (rocks) but you can change their form (like sediments to metamorphic)

- It's the fact that no matter is made or destroyed only changes form.

- No new matter is made and no matter that allready exists can be destroyed.

- No matter is destroyed nor created. (no delayed post score)

- Matter is not created or destroyed.

- matter neither builds or destroys but change all the time rocks neither build or destroy but change all the time (written with two bullet points, no delayed post score) 
- law of conservation of matter is neither destroyed or created

- Matter (or in this case, rocks) is not created or destroyed.

- New rocks arnt made they are only changed.

\section{Point: Partial Understanding of Law of Conservation of Matter}

- Nothing is changed or formed $\rightarrow$ created.

- Destructive forces and constructive forces.

- That rocks never get destroyed they just change.

- No new rocks are made they just change in form

- Rocks are always going through the rock cycle. constructive forces build to a rock and destructive destroys rocks (no delayed post score)

\section{Points: No answer or unable to code}

- Everything is matter (no delayed post score)

- A rock (no delayed post score)

- all rock are made of minerals

\section{Delayed Post-Test}

\section{Question 1: What does the "Law of Conservation of Matter" explain with regard to the rock cycle?}

\section{Points: Full Understanding of Law of Conservation of Matter and the rock cycle}

- Matter can not be destroyed or built You can not build rocks or destroy. Always matter.

- Rocks never get destroyed or created just changed.

- New Matter isn't created. Its only changed. Like Rocks they change to other rocks. 
- It means matter is neither created nor destroyed and its like the rock cycle because thats rock does it is in this case the matter.

- It states that nothing is either created nor destroyed, but it is always changing, just like the rocks in the rock cycle.

- Matter is neither created or destroyed it only changes form. A rock goes through many forms but its matter stays the same

- new matter is never made or destroyed it is reused just like in the rock cycle

- The law of conservation of matter is that no matter is destroyed or made just changing. This relates to the rock cycle because over time rock is only changed.

- law of conservation of matter: matter is neither created or destroyed. this connects to the rock cycle because in the rock cycle matter is not made of destroyed... it is changed.

- matter cannot be destroyed or builded. (there can never be new rocks or rocks that can be eliminated) A rock always come back in different forms

- The "Law of Conservation of Matter" means the a rock can be changed by forces. but nothing is being made new or destroyed.

\section{Points: Full Understanding of Law of Conservation of Matter}

- matter is neither created or destroyed, so rocks are neither created or destroyed

- it means no new matter is made or destroyed. it only changes

- That nothing ever disappears it just changes. Like when a rock erodes from water it mixs with the water to make salt water. Or when Lava and water or cold, gasses air

- The law of conservation of matter refers to how no new matter is created or destroyed. In the rock cycle no new matter is made or destored

- The law of conservation of matter means that rocks can be changed by forces but no rock can be destroded. 
- The law of conservation of matter is the law that new matter is not made, and matter is not destroyed. This ties in with the rock cycle because no new rocks are made or destroyed.

\section{Point: Partial Understanding of Law of Conservation of Matter}

- no new matter is added or destroyed

- That everything changes like in the Rock Cycle

- A rock cannot be destroyed, it can only change.

\section{O Points: No answer or uncodable}

- no answer $=3$

- Forgot

Total number of students with delayed post-test scores $=24$ 


\section{Appendix B: Scoring Guide for Question 2 on Pre-Post and Question 1 on Delayed Post-Test.}

Table 1: Scoring Guide for Question on the Law of Conservation of Matter

\begin{tabular}{|c|c|}
\hline Points & Criteria \\
\hline $\begin{array}{l}\text { 3- Full } \\
\text { Understanding of } \\
\text { Law of } \\
\text { Conservation and } \\
\text { how it relates to } \\
\text { the rock cycle }\end{array}$ & $\begin{array}{l}\text { Student answer uses correct vocabulary demonstrating a full } \\
\text { understanding of the concept of conservation of matter as it relates to } \\
\text { the rock cycle. } \\
\text { Answer demonstrates a full understanding of the law of conservation } \\
\text { of matter through the following three parts: } \\
\text { - Matter cannot be created ( } 1 \text { point). } \\
\text { - Matter cannot be destroyed ( } 1 \text { point). } \\
\text { - Matter changes form OR matter/rocks change form through } \\
\text { the rock cycle ( } 1 \text { point). }\end{array}$ \\
\hline $\begin{array}{l}\text { 2-Full } \\
\text { Understanding of } \\
\text { the Law of } \\
\text { Conservation of } \\
\text { Matter }\end{array}$ & $\begin{array}{l}\text { Student answer uses correct vocabulary demonstrating a full } \\
\text { understanding. } \\
\text { Answer is missing one of the three main parts of the concept, but } \\
\text { includes the following: } \\
\text { - Either one of two answers: Matter cannot be created or } \\
\text { matter cannot be destroyed ( } 1 \text { point). } \\
\text { Either one of two answers: Matter changes form OR } \\
\text { matter/rocks change form through the rock cycle ( } 1 \text { point). }\end{array}$ \\
\hline $\begin{array}{l}\text { 1-Partial } \\
\text { Understanding of } \\
\text { the Law of } \\
\text { Conservation of } \\
\text { Matter }\end{array}$ & $\begin{array}{l}\text { Student shows a partial understanding of the law of conservation of } \\
\text { matter using some correct vocabulary. } \\
\text { Answer is missing two of the three main parts of the concept, but } \\
\text { includes only one of the following: } \\
\text { - Matter cannot be created ( } 1 \text { point). } \\
\text { - Matter cannot be destroyed ( } 1 \text { point). } \\
\text { - Matter changes form OR matter/rocks change form through } \\
\text { the rock cycle ( } 1 \text { point). }\end{array}$ \\
\hline $\begin{array}{l}0 \text {-No answer or } \\
\text { unable to code }\end{array}$ & $\begin{array}{l}\text { Student shows a lack of understanding of the law of conservation of } \\
\text { matter and the vocabulary associated with it, or no answer was } \\
\text { given. }\end{array}$ \\
\hline
\end{tabular}




\title{
Appendix C: Pre-Test
}

\author{
Rocks and Minerals Pre-Assessment
}

1. What is the rock cycle? (You can use words to describe it or draw a diagram)

2. What does the "Law of Conservation of Matter" explain with regard to the rock cycle?

3. Metamorphic rocks form by

a. Changes in temperature and pressure of rocks

b. Molten material (magma) cooling and solidifying

c. Weathering and erosion of rocks

4. Sedimentary rocks form by

a. Weathering and erosion of rocks

b. Changes in temperature and pressure of rocks

c. Molten material (magma) cooling and solidifying

5. Igneous rocks form by

a. Molten material (magma) cooling and solidifying

b. Compaction and cementation of rock material

c. Changes in temperature and pressure of rocks

6. What is the difference between a rock and a mineral?

a. Rocks are composed of one or more minerals

b. Minerals are made up of one or more types of rock

c. There is no difference between rocks and minerals

7. Which of the following is an example of the geologic process of erosion?

a. Soil formation

b. The Oregon sand dunes

c. A river carving through a piece of land like the Grand Canyon 
8. Rocks stay the same, they do not change over time.

a. True

b. False 


\title{
Appendix D: Post-Test
}

\author{
Rocks and Minerals Unit \\ Post Assessment
}

1. Draw a diagram of the rock cycle. Include the three types of rock and label all of the arrows that go between the rock types.

2. What does the "Law of Conservation of Matter" explain with regard to the rock cycle?

3. Metamorphic rocks are formed by

a. The cooling and hardening of lava or magma

b. Compaction and cementation

c. Intense heat and pressure and sometimes hot watery liquids

4. Sedimentary rocks are formed by

a. Intense heat and pressure and sometimes hot watery liquids

b. Compaction and cementation of broken down rock material

c. The cooling and hardening of lava or magma

5. Igneous rocks are formed by
a. The cooling and hardening of lava or magma
b. Compaction and cementation
c. Intense heat and pressure and sometimes hot watery liquids

6. What is the difference between a rock and a mineral?

a. Rocks are composed of one or more minerals

b. Minerals are made up of one or more types of rock.

c. There is no difference between rocks and minerals.

7. A constructive force is

a. A force that destroys

b. A force that builds

c. A force that allows rocks to disappear from the rock cycle. 
8. What processes would an igneous rock have to go through to become a sedimentary rock?

a. Weathering and erosion, then compaction and cementation

b. Heat and pressure, then melting and cooling

c. Melting and cooling, then weathering and erosion

9. An extrusive igneous rock

a. Cools very slowly, forming visible grains and crystals

b. Cools very quickly, and sometimes has holes such as those found in pumice

c. Cools very slowly below Earth's surface

10. The difference between weathering and erosion is:

a. Weathering is a force that builds, and erosion is a force that destroys.

b. Weathering causes rocks to be break down into smaller pieces, and erosion moves sediments from one place to another.

c. Weathering happens to igneous rocks, and erosion only happens to sedimentary rocks.

11. Intrusive igneous rocks are formed

a. Near bodies of water

b. Above the Earth's surface

c. Below the Earth's surface

12. What are igneous rocks made of?

a. Lava and magma

b. Layers of sediments

c. Other rocks that have been exposed to intense heat and pressure

13. Rocks do not change, they stay the same over time.

a. True

b. False

14. Processes like weathering and erosion take place over thousands if not millions of years.

a. True 


\section{b. False}

15. Granite, pumice, and scoria are igneous rocks. Why doesn't granite have little air holes like the other two?

16. Where does the magma that forms igneous rock come from?

17. Draw and label a foliated metamorphic rock and a non-foliated metamorphic rock. Make sure the drawings look different and it is clear you understand the difference between the two. 


\section{Appendix E: Delayed Post-Test}

What does the "Law of Conservation of Matter" explain with regard to the rock cycle?

Where does the magma that forms igneous rock come from? Be specific

In your own words, describe the time scale in which the processes of weathering and erosion take place?

Using the vocabulary words from the rocks and minerals unit, draw a diagram of the rock cycle. 


\section{Appendix F: Human Subjects Approval}

Human Subjects Research Review Committee

Post Office Box 751

503-725-4288 tel

$\begin{array}{ll}\text { Portland, Oregon 97207-0751 } & 503-725-3416 \text { fax } \\ \text { hsrrc@lists.pdx.ed }\end{array}$

June 1, 2010

To: Shirley Tremel

From: Nancy Koroloff, HSRRC Chair

Re: Approval of your application titled, "Investigating the Effects of Differentiated Instruction in a Middle School Science Unit" (HSRRC Proposal \# 101339).

Dear Shirley,

In accordance with your request, the Human Subjects Research Review Committee has reviewed your proposal referenced above for compliance with DHHS policies and regulations covering the protection of human subjects. The committee is satisfied that your provisions for protecting the rights and welfare of all subjects participating in the research are adequate, and your project is approved. Please note the following requirements:

Changes to Protocol: Any changes in the proposed study, whether to procedures, survey instruments, consent forms or cover letters, must be outlined and submitted to the Chair of the HSRRC immediately. The proposed changes cannot be implemented before they have been reviewed and approved by the Committee.

Continuing Review: This aptroval will extire on June 1.2011 It is the investigator's responsibility to ensure that a Continuing Review Report (available in ORSP) of the status of the project is submitted to the HSRRC two months before the expiration date, and that approval of the study is kept current.

Adverse Reactions: If any adverse reactions occur as a result of this study, you are required to notify the Chair of the HSRRC immediately. If the problem is serious, approval may be withdrawn pending an investigation by the Committee.

Completion of Study: Please notify the Chair of the Human Subjects Research Review Committee (campus mail code ORSP) as soon as your research has been completed. Study records, including protocols and signed consent forms for each participant, must be kept by the investigator in a secure location for three years following completion of the study.

If you have questions or concerns, please contact the HSRRC in the Office of Research and Sponsored Projects (ORSP), (503) 725-4288, 6th Floor, Unitus Building, 4th \& Lincoln.

Cc: William Becker 


\begin{tabular}{lll}
\multicolumn{1}{c}{ from } & shirley tremel<shirlspdx@gmail.com> & \\
to & dvenna_carlson@beavton.k12.or.us & \\
date & Fri, Jun 4,2010 at 4:00 PM & hide details Jun 4 \\
subject & Human Subjects Review &
\end{tabular}

mailed-by gmail.com

Hello Ms. Carlson,

I am currently student teaching at Highland Park Middle School as part of my teaching program at Portland State University. I understand that you are no longer reviewing applications for research involving students within your district. I am writing to see if there is any way I can still seek approval for an application that has already been approved through Portland State University. My study poses VERY minimal risk to students as I am only asking to use student work from a recent unit I taught. The data I would be using upon approval was a part of regular classroom instruction. There are no interviews, videotape recordings or audio recordings, only access to student work. I will be analyzing student work to learn more about student misconceptions in Earth science in order to inform my practice and to make that information available to other teachers who wish to improve their teaching around this subject area.

I apologize for submitting an application so late in the year and I will understand if there is no possible way for it to be approved until next Fall. I am attaching my proposal and my letter of approval from PSU Human Subjects Research Review Committee. In addition, I will drop off a copy of my application with the accompanying signed materials to the district office on Monday morning. If you have any questions please contact me by email. You may also contact Carol Biskupic Knight who is partnered with my teaching program through the Center for Science Education and Beaverton School District, or Jennifer Wells at the Center for Science Education. Carol's email address is bis2@pdx.edu. You may reach Jennifer Wells (program coordinator) by email: wellj@pdx.edu or by phone at 503-725-8345.

Thank you for your consideration in this matter.

Shirley Tremel 971-222-9424

\author{
from Dvenna Carlson <Dvenna_Carlson@beavton.k12.or.us> \\ to $\quad$ shirlspdx@gmail.com \\ date Sun, Jun 6, 2010 at 4:39 PM \\ subject Re: Human Subjects Review \\ mailed-by beavton.k12.or.us
}

Your propsal is approved if the following conditions are met

1. You are only working with students assigned to your regular classrooms

2.You are doing nothing that is not a part of general classroom instruction.

shirley tremel show details Jun 6

to Dvenna 
Hello,

Thank you for your response. I really appreciate it! My study definitely meets both of the conditions you listed. I will bring by a copy of the application signed by myself and my advisor, and a copy of my proposal and acceptance letter from PSU. Do you know if I still need to do the background check even though I have already done one through TSPC and Portland Public

Schools? If so, I will gladly bring a $\$ 5$ check as well. Should I contact you directly tomorrow, or leave the paperwork in your mailbox?

Thank you!

-Shirley Tremel

Dvenna Carlson show details Jun 7

to me

I don't even need a copy. It falls under the a category of project that we do not have to review

\title{
shirley tremel show details Jun 7
}

to Dvenna

Thanks Dvenna,

Should I just print your email as proof of your approval? I am guessing I'll need to have some documentation. Thanks, Shirley

\author{
from_Dvenna Carlson <Dvenna_Carlson@beavton.k12.or.us> \\ to $\quad$ shirlspdx@gmail.com \\ date Mon, Jun 7, 2010 at 9:00 AM \\ subject Re: Human Subjects Review \\ hide details Jun 7 \\ mailed-by beavton.k12.or.us
}

A copy of my email should do 


\section{Appendix G: Letter of Informed Consent}

Dear Parent or Guardian:

Your child is invited to participate in a research study lead by myself, Ms. Tremel, a graduate student at Portland State University. I have been student teaching in Ms. Weller's science class since December, 2009. As part of my teaching program, I have an opportunity to conduct research looking at student understanding of fundamental concepts in Earth science.

Your child's participation is voluntary. If you allow your child to participate, I will look at the work generated during a recent rocks and minerals unit, including lab handouts, daily warm-ups, quizzes, tests, projects, and attendance data.

Information obtained from this research that could identify your child will be kept confidential to the extent allowable by law (mandated reporting laws require knowledge of child abuse to be reported, regardless of research participation). Strict record keeping will be maintained to ensure confidentiality and privacy. All records will be stored in a secure location in Epler Hall, Room 101, at Portland State University, and will be destroyed by August 2013.

Your child does not have to participate in any part of the research. Lack of participation will not affect his/her relationship with the researcher, Beaverton Public Schools, or Portland State University. Your child may withdraw from the study at any time without penalty.

If you have concerns or questions about your child's participation in this study or your rights as a research participant, please contact the Human Subjects Research Review Committee, Office of Research and Sponsored Projects, 600 Unitus Bldg., Portland State University, 503-725-4288. For questions about the study itself, contact Shirley Tremel at shirlspdx@gmail.com or Dr. Sybil Kelley, 503-725-8345 sybilkel@pdx.edu.

Thank you for your child's participation in this research.

Sincerely,

Shirley Tremel

MST Candidate in General Science

Center for Science Education-Portland State University

Your signature indicates that you have read and understand the above information and agree to allow your child to take part in this study. Please understand that you may withdraw your consent at any time without penalty.

Yes, I will allow my child to participate in this research study as indicated below

Notes from classroom observations

Routine classroom work (homework, projects, tests quizzes and lab handouts from Rocks and

Minerals Unit

$\overline{\text { Signature }} \overline{\text { Date }}$

Printed Name 